\title{
Reclaiming the memory of pioneer female geologists 1800-1929
}

\author{
Aude Vincent \\ École Normale Supérieure-PSL Université and CNRS, UMR.8538 Laboratoire de Géologie, 24 rue Lhomond, \\ 75231 Paris CEDEX 05, France
}

Correspondence: Aude Vincent (aude.vincent@ normalesup.org)

Received: 7 December 2019 - Revised: 16 April 2020 - Accepted: 21 May 2020 - Published: 4 August 2020

\begin{abstract}
Female earth scientists existed in the 19th century and the beginning of the 20th century in a number exceeding what we generally imagine. In this paper I present information on 210 of them who were active from 1800 to 1929. These women often overcame great challenges to achieve their positions, sometimes only to have their work attributed to men they worked with or for. Gender discrimination made access to university difficult and access to scientific careers even harder. They found several ways to overcome these difficulties thanks to the support of their parents or to the more ambiguous support of husbands or academic male mentors, through staying single, and through teamwork and mentorship with other women.

In the same way many past female artists have been recently rediscovered, women scientists are progressively being saved from the dustbin of history, a huge task that has already been undertaken by several researchers. In addition to the review of their research, a fresh contribution to this collective work in progress is made with the presentation of hydrogeologist Norah Dowell Stearns. Finally, some reflections and suggestions are included on how we could fight this oblivion to which their work, their personalities and modern research on them are subject to.
\end{abstract}

\section{Introduction}

I should confess that until 2018 the only female geologist from the 19th century I knew was Mary Anning, the palaeontologist. I was no different than most people in that I was able to name one female geologist - and people able to name one are a minority (Burek, 2009; Burek and Higgs, 2007). Curious to see whether a few others had existed, I started searching in the scientific literature and in blogs. And I found many (many) more than I thought I would. I have compiled a list of
210 geologists and palaeontologists active between 1800 and 1929 (see Table 1 and the Supplement). I found them mainly in the scientific literature by looking into their history (see Sect. 2 "Methodology") and in one case through her publications (see Sect. 8 "Focus on a new discovery: Norah Dowell Stearns"). As a comparison, 23 female geoscientists were active in the USA in 1921 (and 60 in 1938; Rossiter, 1982) compared to 630 men (1425 in 1938; Rossiter, 1982), women thus representing $3.7 \%$ of USA geoscientists in 1921 (4.2\% in 1938; Rossiter, 1982). I am not aware of data giving the evolution of the number of geologists worldwide from 1800 to the early 20th century, but today women represent about a third of geoscientists (e.g. Holmes et al., 2011), so progress has been made.

The list I established is certainly not exhaustive. In the same way as many past female artists are discovered anew, women scientists are progressively saved from the dustbin of history. Thus we realise that even if undertaking studies and a scientific career meant then even more than now facing obstacles (see Sect. 4 "Discrimination"), some women managed it. Not only did they find time to pursue their scientific research but to also be active in social issues (see Sect. 9 "Scientists and activists").

The first question which arises is how they overcame difficulties. Familial support and specific familial configuration were an important basis (see Sect. 5 "Overcoming discrimination 1: family configuration and support"), more or less ambiguous or interested support given by male geologists being a frequent way (see Sect. 6 "Overcoming discrimination 2 : in the shadow of "great men"'), and finally strong links between female scientists was a solid factor (see Sect. 7 "Overcoming discrimination 3: sorority”).

The second question is why we cannot remember hardly any of them if there were so many. Was all their work unimportant and negligible? The many examples of substan- 
tial contributions (see Sect. 3 "Some major contributions") clearly state that this "negligible work" hypothesis does not make sense. There must be something else, and most probably several mechanisms: from the shadow of men they worked with (see Sect. 6 "Overcoming discrimination 2: in the shadow of "great men"') to the way science history is written and transmitted (which is the question explored in Sect. 10 "Obliteration"). All these sexist mechanisms form what Margaret Rossiter named the Matilda effect (Rossiter, 1993).

\section{Methodology}

This paper is mainly a review of the existing literature on the role of women in the history of earth sciences. The biographical dictionary of women in science established under the direction of Marilyn B. Ogilvie and Joy D. Harvey in 2000 has been a particularly rich resource, using all the available sources (in particular Mary R.S. Creese and Thomas M. Creese publications in the 1990s; Sarjeant, 1978-1987; Aldrich, 1982) and making the data collected by Nalivkin in Russian accessible in English (Nalivkin, 1979). Of the 210 women geologists listed in Table 1 and the Supplement, 153 have an entry in Ogilvie and Harvey (2000). The book by Margaret Rossiter on American women scientists was of course another important source (Rossiter, 1982) as was the special publication of the London Geological Society in 2007 coordinated by Cynthia V. Burek and Bettie Higgs (Burek and Higgs, 2007).

Several blogs of science popularisation have helped me discover new figures and sources about them, especially TrowelBlazers (https://trowelblazers.com, last access: 2019), Letters from Gondwana (https://paleonerdish. wordpress.com, last access: 2019), and Women in American Paleontology (http://www.daringtodig.com, last access: 2019).

Many of the women came to my attention as co-authors, collaborators or students of other women as female scientists often developed strong sorority networks (see Sect. 7 "Overcoming discrimination 3: sorority").

Original new data on one of the female pioneers of hydrogeology, Norah Dowell Stearns (see Sect. 8 "Focus on a new discovery: Norah Dowell Stearns"), are presented in this paper. I found her by going through the authors of early 20th-century hydrogeological publications, looking for female first names. For many women scientists that are probably still unknown, there might not be any other way to find them than to literally dig into historical scientific publications from a specific field or into private correspondence of scientists when available. This should especially be carried out when confronted with an apparent vacuum, i.e. a geographical area or a geoscience subject counting apparently no female scientists in the past. As is well known in earth sciences, "the absence of evidence is not the evidence of absence".

The choices of limits for the list presented in Table 1 and the Supplement and discussed in this paper are the following:

- Timewise, 1800-1929. Women who have been considered active from the beginning of the 19th century, when geology was firmly established as a modern science and blooming (in a close relationship to the Industrial Revolution; see e.g. Osborne, 2013), and who started their research career in 1929 at the latest. From the 1920s universities and associations still inaccessible to women were an exception and no longer the norm, at least in the industrialised world (Hulbe et al., 2010).

- Subject-wise. All earth sciences are considered, but neither archaeologists, prehistorians, astronomers nor planetary scientists are included.

- Research. All the women scientists mentioned here did some research, attested either by publications; significant fossils or rocks collections; or acknowledgements by others of their participation in field work, data discussions or publication writing and key illustrations. Thus, authors involved in the popularisation of science only are not included (for those see e.g. Larsen, 2017).

A total of 34 additional women who could match these criteria were not included due to lack of (access to) information on them.

To lighten the reading, references used for each woman geologist are not included in the text but in the table presenting them all (Table 1).

\section{Some major contributions}

The works presented in Table 2 are a subjective selection among all the remarkable studies produced or co-produced by the 210 women geologists listed in Table 1 and the Supplement. The intent is not to be exhaustive (at least a fulllength paper would be necessary for that) but to give an overview of the diversity of their most impressive works.

\section{Discrimination}

Sexist discrimination took many forms where women studied, in their work place and in the family unit, making it a challenge for women in science to do research. In addition to this they had difficulty feeling legitimate and at ease due to the general disapprobation and the small percentage of women in institutions (except for female-only colleges). It is almost overwhelming to think of all the women who never came back to science or never started in the first place because of sexism (a problem that persists today). 
Table 1. Female geologists (earth sciences, excluding astronomy and prehistory), 19th century and 1900-1929: bibliographical references. See the Supplement for more information on each of them.

\begin{tabular}{|c|c|c|c|}
\hline Last name 1 & $\begin{array}{l}\text { Last name } 2 \\
\text { (marriage) }\end{array}$ & First name & References \\
\hline Adametz & Kittl & Lotte & Ogilvie and Harvey (2000) \\
\hline Adams & Fenton & Mildred & U. of Iowa libraries (2019) \\
\hline Adamson & Hobson & Margaret & Turner (2007) \\
\hline Alexander & - & Annie M. & $\begin{array}{l}\text { Ogilvie and Harvey (2000); Kölbl-Ebert and Turner (2016); U. of California Museum of Pale- } \\
\text { ontology (2019) }\end{array}$ \\
\hline Anderson & Gray & Elizabeth & TrowelBlazers blog; Creese (2007) \\
\hline Anning & - & Mary & $\begin{array}{l}\text { Turner et al. (2010); Ignotofsky (2016); Ogilvie and Harvey (2000); Goodhue (2005); Creese } \\
\text { and Creese (1994); Davis (2009) }\end{array}$ \\
\hline Arner-Boyd & - & Louise & Ogilvie and Harvey (2000); Hulbe et al. (2010) \\
\hline Atkinson & Calvert & Louisa & Ogilvie and Harvey (2000); Turner (2007) \\
\hline Baber & - & Zonia (Mary A.) & Ogilvie and Harvey (2000) \\
\hline Bancroft & & Nellie & Ogilvie and Harvey (2000); Fraser and Cleal (2007) \\
\hline Barnard & Greenly & An(nie) & Burek (2014); Williams (2007) \\
\hline Bascom & - & Florence & $\begin{array}{l}\text { Ogilvie and Harvey (2000); Rossiter (1982); Schneiderman (1997); Clary and Wander- } \\
\text { see (2007); Ignotofsky (2016); Daring to Dig - Florence Bascom (2019) }\end{array}$ \\
\hline Bate & - & Dorothea M. A. & Ogilvie and Harvey (2000); Hart (2007) \\
\hline Belaeva & & Elizaveta I. & Ogilvie and Harvey (2000) \\
\hline Benett & - & Etheldred & $\begin{array}{l}\text { Ogilvie and Harvey (2000); Burek and Kölbl-Ebert (2007); Creese and Creese (1994); Laming } \\
\text { and Laming (2007); Turner et al. (2010) }\end{array}$ \\
\hline Benson & - & Margaret & Ogilvie and Harvey (2000); Fraser and Cleal (2007) \\
\hline Bentivoglio & & Marie & Turner (2007); Bygott and Cable (1985) \\
\hline Berridge & & Emily M. & Ogilvie and Harvey (2000); Fraser and Cleal (2007) \\
\hline Birley & - & Caroline & TrowelBlazers - Caroline Birley (2019); anonymous (1907) \\
\hline Blackburn & - & Kathleen B. & Ogilvie and Harvey (2000); Hart (2007) \\
\hline Bliss & Knopf & Eleanora & Ogilvie and Harvey (2000); Hulbe et al. (2010) \\
\hline Bolton & Helsby & Edith & Fraser and Cleal (2007) \\
\hline Bowdick & Lee & Sarah W. & Ogilvie and Harvey (2000); Orr (2019); Creese and Creese (1994) \\
\hline Brenchley & & Winifred E. & Ogilvie and Harvey (2000); Fraser and Cleal (2007) \\
\hline Brezina & & Maria A. & Ogilvie and Harvey (2000) \\
\hline Brown & Browne & Ida & Ogilvie and Harvey (2000); Turner (2007) \\
\hline Buckley & Fisher & Arabella & Ogilvie and Harvey (2000) \\
\hline Carter & Edson & Fanny & Ogilvie and Harvey (2000); Rossiter (1982) \\
\hline Cary & Agassiz & Elizabeth C. & Ogilvie and Harvey (2000); History of American Women w \\
\hline Céline & Leclercq & Suzanne & Ogilvie and Harvey (2000) \\
\hline Chaudet & & Maria C. & Ogilvie and Harvey (2000) \\
\hline Chorley & Crosfield & Margaret & $\begin{array}{l}\text { Ogilvie and Harvey (2000); Burek (2014); Burek and Malpas (2007); Burek and Higgs (2007); } \\
\text { Letters from Gondwana w }\end{array}$ \\
\hline Cohen & & Fanny & Turner $(2007)$ \\
\hline Congreve & - & Sarah & Turner et al. (2010) \\
\hline Congreve & - & Mary & Turner et al. (2010) \\
\hline Cookson & & Isabel C. & Ogilvie and Harvey (2000); Turner (2007) \\
\hline Copland & - & Louisa & cf. Caroline Birley \\
\hline Cotter & - & E. & Higgs and Jackson (2007) \\
\hline Crane & & Agnes & Ogilvie and Harvey (2000); Creese and Creese (1994) \\
\hline Crawford-MacDowall & Wright & Mabel & Higgs and Jackson (2007) \\
\hline Crespin & & Irene & $\begin{array}{l}\text { Ogilvie and Harvey (2000); Turner (2007); Letters from Gondwana Forgotten women of pale- } \\
\text { ontology: Irene Crespin (2019) }\end{array}$ \\
\hline Crié & Oehlert & Pauline E. & Kölbl-Ebert and Turner (2016);Daniel Victor Oehlert (2019) \\
\hline De Fraine & & Ethel & Ogilvie and Harvey (2000); Fraser and Cleal (2007) \\
\hline Delvalle & Lowry & Rebekah & Kölbl-Ebert and Turner (2016) \\
\hline Dingwall & Harrison & Janet M. M. & Ogilvie and Harvey (2000) \\
\hline Dix & - & Emily & $\begin{array}{l}\text { Burek and Cleal (2005); Fraser and Cleal (2007); Burek and Kölbl-Ebert (2007); Burek (2014); } \\
\text { TrowelBlazers - Emily Dix (2019) }\end{array}$ \\
\hline Dobbie & Curie & Ethel & Ogilvie and Harvey (2000) \\
\hline Dobrolubova & - & Tatiana & Ogilvie and Harvey (2000) \\
\hline Donald & Longstaff & Jane & $\begin{array}{l}\text { Creese and Creese (1994); Ogilvie and Harvey (2000); Burek and Higgs (2007); TrowelBlazers } \\
\text { - Jane Donald Longstaff (2019) }\end{array}$ \\
\hline Dowell & Stearns & Norah & Her publications; Davis and Davis (2005); Stearns (1983) \\
\hline Drew & & Helen & Burek (2014) \\
\hline Drummond-Smith & Cotton & Catherine & Turner (2007) \\
\hline Edinger & - & Tilly & Ogilvie and Harvey (2000); Turner et al. (2010) \\
\hline
\end{tabular}


Table 1. Continued.

\begin{tabular}{|c|c|c|c|}
\hline Last name 1 & $\begin{array}{l}\text { Last name } 2 \\
\text { (marriage) }\end{array}$ & First name & References \\
\hline Elles & - & Gertrude L. & Ogilvie and Harvey (2000); Higgs and Jackson (2007); Burek (2014); Tubb and Burek (2019) \\
\hline Ellisor & - & Alva C. & Ogilvie and Harvey (2000); Rossiter (1982); Gries (2017) \\
\hline Eyton & - & Charlotte & Ogilvie and Harvey (2000); Creese and Creese (1994) \\
\hline Fairfax & Somerville & Mary & $\begin{array}{l}\text { Ogilvie and Harvey (2000); Hulbe et al. (2010); Higgs and Jackson (2007); Hart (2007); Chazal } \\
\text { (2005) }\end{array}$ \\
\hline Fisher & - & Elizabeth F. & Shrock (1982); Ogilvie and Harvey (2000) \\
\hline Foley & & Cecilia M. & Ogilvie and Harvey (2000); Creese and Creese (1994) \\
\hline Folmer & - & Hermine $\mathrm{J}$. & Ogilvie and Harvey (2000) \\
\hline Forster & - & Mary & Ogilvie and Harvey (2000); Creese and Creese (1994) \\
\hline Foster & & Margaret & $\begin{array}{l}\text { Rossiter (1982); Dowell Stearns (1927); Howes and Herzenberg (1999); Ogilvie and Harvey } \\
\text { (2000) }\end{array}$ \\
\hline Fowler- & Billings & Katherine (Kay) S. & Ogilvie and Harvey (2000); Frost (2017) \\
\hline Francis & Child & Lydia M. & Ogilvie and Harvey (2000) \\
\hline Fritz & - & Madeleine A. & Ogilvie and Harvey (2000); Monteigh (1992); Burke (2008-2014) \\
\hline Fuller & Boos & Margaret B. & Ogilvie and Harvey (2000) \\
\hline Furlani & Cornelius & Marta & Ogilvie and Harvey (2000) \\
\hline Gardiner & - & Margaret I. & Ogilvie and Harvey (2000); Creese and Creese (1994) \\
\hline Gardner & - & Julia A. & Rossiter (1982); Ogilvie and Harvey (2000); Daring to Dig - Julia Gardner (2019) \\
\hline Gardner & & Elinor W. & Ogilvie and Harvey (2000) \\
\hline Goldring & - & Winifred & Rossiter (1982); Ogilvie and Harvey (2000) \\
\hline Goodyear & & Edith & Ogilvie and Harvey (2000); Jackson and Spencer Jones (2007) \\
\hline Gordon- & Cumming & Eliza M. & Burek and Higgs (2007); Ogilvie and Harvey (2000) \\
\hline Gortynskaia & Pavlova & Maria V. & Creese (2007); Creese (2015); Ogilvie and Harvey (2000) \\
\hline Graham & Callcott & Maria & $\begin{array}{l}\text { Creese and Creese (1994); Ogilvie and Harvey (2000); Thompson (2019); TrowelBlazers - } \\
\text { Maria Graham (2019) }\end{array}$ \\
\hline Gray & & Edith & TrowelBlazers - Elizabeth Anderson Gray (2019) \\
\hline Gray & & Alice & TrowelBlazers - Elizabeth Anderson Gray (2019) \\
\hline Guppy & - & Eileen & Bowie (2007); TrowelBlazers - Eileen Guppy (2019); Pennington (2015) \\
\hline Heermann & - & Margareta & Ogilvie and Harvey (2000) \\
\hline Hendricks & - & Eileen M. L. & Ogilvie and Harvey (2000); Bowie (2007); Bennett and Mather (2019) \\
\hline Hodgson & & Elizabeth & Ogilvie and Harvey (2000); Hart (2007); Creese and Creese (1994) \\
\hline Hofmann & & Elise & Ogilvie and Harvey (2000) \\
\hline Holmes & - & Mary Emily & Ogilvie and Harvey (2000); Bryan et al. (2010) \\
\hline Hone & Smith & Mary & Turner et al. (2010) \\
\hline Horner & Lyell & Mary & Ogilvie and Harvey (2000); Ashcraft (1998); TrowelBlazers - Mary Horner Lyell (2019) \\
\hline Howard & Wyldi & Hildegarde & Ogilvie and Harvey (2000) \\
\hline Hoyermann & & Tekla & Kölbl-Ebert and Turner (2016) \\
\hline Hugonin & Murchison & Charlotte & $\begin{array}{l}\text { Kölbl-Ebert (1997); Jackson and Spencer Jones (2007); TrowelBlazers - Charlotte Murchison } \\
\text { (2019) }\end{array}$ \\
\hline Hult & de Geer & Ebba & Hulbe et al. (2010) \\
\hline Hüther & Richter & Emma & Ogilvie and Harvey (2000) \\
\hline Jewell-Glass & - & Jeannette & Ogilvie and Harvey (2000); Rossiter (1982) \\
\hline Johnston & & Mary S. & Ogilvie and Harvey (2000); Burek (2014) \\
\hline Jonas & Stose & Anna & Ogilvie and Harvey (2000); Jones and Scharnberger (2012); Dietrich (1977) \\
\hline Kaplanova & Slavikova & Ludmila & Ogilvie and Harvey (2000) \\
\hline Kelly & & Agnes & Ogilvie and Harvey (2000); Creese and Creese (1994) \\
\hline Kemper & Palmer & Dorothy B. & Ogilvie and Harvey (2000) \\
\hline King & - & Georgina & Ogilvie and Harvey (2000) \\
\hline Kingdon & Heslop & Mary & Ogilvie and Harvey (2000); Burek (2008) \\
\hline Kingsley & & Louise & Ogilvie and Harvey (2000) \\
\hline Klaassen & Scott & Henderina V. & Ogilvie and Harvey (2000); Fraser and Cleal (2007) \\
\hline Klenova & & Maria K. & Anonymous (2003); Reed and Cannon (2009) \\
\hline Knaggs & & Isobel & Burek (2019) \\
\hline Kniker & - & Hedwig T. & $\begin{array}{l}\text { Ogilvie and Harvey (2000) entry "E. Richards Applin"; Gries (2017); Briscoe Center for Amer- } \\
\text { ican History (2019); Jackson School Museum of Earth History (2019) }\end{array}$ \\
\hline Knote & Ebers & Edith & Ogilvie and Harvey (2000) \\
\hline Lane & Weinzierl & Laura L. & Ogilvie and Harvey (2000) \\
\hline Le Maître & - & Dorothée & Ogilvie and Harvey (2000) \\
\hline Lehmann & - & Inge & $\begin{array}{l}\text { Ogilvie and Harvey (2000); TrowelBlazers - Inge Lehmann (2019); Encyclopedia Britannica } \\
\text { (2019); American Museum of Natural History (2019) }\end{array}$ \\
\hline Lindsey & & Marjorie & Fraser and Cleal (2007) \\
\hline Livesey & Reynolds Holmes & Doris & Ogilvie and Harvey (2000); Higgs and Jackson (2007); Lewis (2019) \\
\hline
\end{tabular}


Table 1. Continued.

\begin{tabular}{|c|c|c|c|}
\hline Last name 1 & $\begin{array}{l}\text { Last name } 2 \\
\text { (marriage) }\end{array}$ & First name & References \\
\hline Lowry & Varley & Delvalle E. & Kölbl-Ebert and Turner (2016); Larsen (2017) \\
\hline Mason & - & Carol Y. & Ogilvie and Harvey (2000) \\
\hline Maury & - & Carlotta $\mathrm{J}$. & Ogilvie and Harvey (2000); Burek and Kölbl-Ebert (2007) \\
\hline Maximilianovna & Rauzer-Cherna/ousova & Dagmara & Ogilvie and Harvey (2000) \\
\hline McGlamery & & Josie W. & Ogilvie and Harvey (2000) \\
\hline McInerny & Sherrard & Kathleen & Grahame (2002); Turner (2007) \\
\hline Mertz & & Ellen L. & Wikipedia in English using sources in Danish (Dansk Biografisk Leksikon) (2019) \\
\hline Mikhailovna & Shubnikova & Olga & Ogilvie and Harvey $(2000)$ \\
\hline Milne & Prestwich (McCall) & Grace & Ogilvie and Harvey (2000); Burek and Higgs (2007); Larsen (2017) \\
\hline Missuna & & Anna B. & Ogilvie and Harvey (2000) \\
\hline Morland & Buckland & Mary & Ogilvie and Harvey (2000); Burek and Jones (2008) \\
\hline Muir-Wood & - & Helen M. & Ogilvie and Harvey (2000); Jackson and Spencer Jones (2007) \\
\hline Munro & & Madeline & Burek (2008) \\
\hline Neuburg & & Maria F. & Ogilvie and Harvey (2000) \\
\hline Newton & Foote & Eunice & Sorenson $(2011,2018)$ \\
\hline Nikolayevna & Sokolskaya & Anna & Ogilvie and Harvey (2000) \\
\hline O’Connell & & Marjorie & Ogilvie and Harvey (2000) \\
\hline Ogilvie & Gordon & Maria M. (May) & $\begin{array}{l}\text { Ogilvie and Harvey (2000); Wachtler and Burek (2007); Burek and Kölbl-Ebert (2007); } \\
\text { Creese and Creese (1994); Scientific American (2019) }\end{array}$ \\
\hline Ogilvie & - & Ida Helen & Ogilvie and Harvey (2000); Hulbe et al. (2010) \\
\hline Owen & & Luella A. & Creese 1998; Ogilvie and Harvey (2000); Creese (2007) \\
\hline Pengelly & Julian & Hester F. & Ogilvie and Harvey (2000) \\
\hline Peyronnet-Browne & - & Isabel & Ogilvie and Harvey (2000); Fraser and Cleal (2007) \\
\hline Phillips & - & Anne & Kölbl-Ebert and Turner (2016); Burek (2007); TrowelBlazers - Anne Phillips (2019) \\
\hline Philpot & - & Mary/Louise & Ogilvie and Harvey (2000) \\
\hline Philpot & - & Elizabeth & Ogilvie and Harvey (2000) \\
\hline Philpot & - & Margaret & Ogilvie and Harvey (2000) \\
\hline Powell & & Dorothy K. "Dip" & Turner (2007) \\
\hline Prankerd & & Theodora L. & Ogilvie and Harvey (2000); Fraser and Cleal (2007) \\
\hline Quodling & & Florence M. & Turner (2007); Encyclopedia of Australian Science (2019) \\
\hline Radler & Hall & Dollie & Rossiter (1982); Gries (2017) \\
\hline Raisin & - & Catherine & $\begin{array}{l}\text { Creese and Creese (1994); Ogilvie and Harvey (2000); Burek and Malpas (2007); Burek } \\
\text { and Kölbl-Ebert (2007); Burek (2014) }\end{array}$ \\
\hline Richards & Applin & Esther & Ogilvie and Harvey (2000); Rossiter (1982); Gries (2017) \\
\hline Robertson & Arber & Agnes & Fraser and Cleal (2007) \\
\hline Rudbeck & Arrhenius & Sofia & Svenska dagstidningar (2019); collective letter (1906) \\
\hline Sahlbom & - & Naima & Svenskt Biografiskt Lexikon (2019); Creese (2007); Creese and Creese (2004) \\
\hline Sanborn & - & Ethel & Ogilvie and Harvey (2000) \\
\hline Scarpollini & & Caterina & Ogilvie and Harvey (2000) \\
\hline Shirokobrumov & Tumanskaya & Olga & Ogilvie and Harvey (2000) \\
\hline Shulga & Nesterenko & Maria I. & Ogilvie and Harvey (2000) \\
\hline Sieverts & Doreck & Hertha & Ogilvie and Harvey (2000) \\
\hline Skeat & Woods & Ethel & Burek and Malpas (2007); Creese and Creese (1994); Ogilvie and Harvey (2000) \\
\hline Skewes & Plummer & Helen J. & Ogilvie and Harvey (2000); Rossiter (1982) \\
\hline Slater & Lees & Ida L. & Ogilvie and Harvey (2000); Consuelo Sendino (2019) \\
\hline Smith & - & Isabel F. & Schneiderman (1992); Ogilvie and Harvey (2000) \\
\hline Sollas & - & Igerna B. J. & $\begin{array}{l}\text { Ogilvie and Harvey (2000); Creese and Creese (1994); Jackson and Spencer Jones } \\
(2007)\end{array}$ \\
\hline Solomko & Viktorovna & Evgenia & Creese 2015; Creese (2007); Ogilvie and Harvey (2000) \\
\hline Soshkina & & Elizabeth D. & Ogilvie and Harvey (2000) \\
\hline Stadnichenko & - & Taisia (Maria) M. & Rossiter (1982); Ogilvie and Harvey (2000); cf. F. Bascom \\
\hline Stefanescu & & Sabba & Ogilvie and Harvey (2000) \\
\hline Stevens & Walcott & Helene B. & Ogilvie and Harvey (2000) \\
\hline Stewart & - & Grace Anne & Ogilvie and Harvey (2000) \\
\hline Stopes & Roe & Marie C. C. & $\begin{array}{l}\text { Ogilvie and Harvey (2000); Fraser and Cleal (2007); Chaloner (2008); Falcon-Lang } \\
\text { (2008) }\end{array}$ \\
\hline Swallow & Richards & Ellen & Ogilvie and Harvey (2000); Dyball and Carlsson (2017) \\
\hline Syniewska & & Janina & Ogilvie and Harvey (2000) \\
\hline Talbot & & Mignon & Ogilvie and Harvey (2000); Turner et al. (2010) \\
\hline Thomas & Williams & Marguerite & $\begin{array}{l}\text { Ogilvie and Harvey (2000); Warren (2000); TrowelBlazers - Marguerite THomas } \\
\text { Williams (2019) }\end{array}$ \\
\hline Thomas Carne & - & Elizabeth C. & Ogilvie and Harvey (2000); Transceltic (2019) \\
\hline Thompson & Christen & Sydney M. & $\begin{array}{l}\text { Higgs and Jackson (2007); Ogilvie and Harvey (2000); Jackson (2009); Creese and } \\
\text { Creese (1994) }\end{array}$ \\
\hline
\end{tabular}


Table 1. Continued.

\begin{tabular}{|c|c|c|c|}
\hline Last name 1 & $\begin{array}{l}\text { Last name } 2 \\
\text { (marriage) }\end{array}$ & First name & References \\
\hline Todtmann & & Emmy M. & Ogilvie and Harvey (2000) \\
\hline Tomlinson & - & Mabel E. & Hart (2007); TrowelBlazers - Mabel E. Tomlinson (2019) \\
\hline Trizna & - & Valentina B. & Ogilvie and Harvey (2000) \\
\hline Tschernaieff & Jérémine & Elisabeth & Ogilvie and Harvey (2000); BnF Data (2019) \\
\hline Tsvetaeva & & Maria & Ogilvie and Harvey (2000); Creese 2015 \\
\hline Tuck & & Margaret $\mathrm{C}$. & Fraser and Cleal (2007) \\
\hline Turutanova-Ketova & & Antonina I. & Kölbl-Ebert and Turner (2016); Lobacheva (2007) \\
\hline Van Winckle & Palmer & Katherine E. H. & Ogilvie and Harvey (2000) \\
\hline Varsanofeva & & Vera A. & Ogilvie and Harvey (2000) \\
\hline Vaux & Walcott & Mary M. & Ogilvie and Harvey (2000); Hulbe et al. (2010) \\
\hline Vernon & Cole & Blanche & Jackson (2007); Higgs and Jackson (2007) \\
\hline Viktororovna Karpova & Semikhatova & Sofia & Ogilvie and Harvey (2000) \\
\hline Vincent & & Adele V. & Turner (2007) \\
\hline Vladinirovna & Lermontova & Ekaterina & Ogilvie and Harvey (2000) \\
\hline Welleck & Garretson & Mary & Ogilvie and Harvey (2000) \\
\hline Weston & McKenny Hugues & Mary C. & $\begin{array}{l}\text { U. of Cambridge Department of Earth Sciences (2019); Ogilvie and Har- } \\
\text { vey (2000); Hart (2007); Creese and Creese (2000) }\end{array}$ \\
\hline Whedon & & Frances L. & Ogilvie and Harvey (2000) \\
\hline White & Hitchcock & Orra & Ogilvie and Harvey (2000); Turner et al. (2010); Daring to Dig (2019) \\
\hline Wigglesworth & - & Grace & Fraser and Cleal (2007) \\
\hline Wills & - & Lucy & Fraser and Cleal (2007) \\
\hline Wilson & - & Alice E. & $\begin{array}{l}\text { Science.ca (2019); The Canadian Encyclopedia (2019); Ogilvie and Harvey } \\
\text { (2000); government of Canada (2019) }\end{array}$ \\
\hline Winearls Porter & - & Mary & $\begin{array}{l}\text { Ogilvie and Harvey (2000); TrowelBlazers - Mary "Polly" Winearls Porter } \\
\text { (2019) }\end{array}$ \\
\hline Wood & Shakespear & Ethel & Creese and Creese (1994); Ogilvie and Harvey (2000); Burek (2014) \\
\hline Woodhouse & Mantell & Mary Ann & Ogilvie and Harvey (2000); Turner et al. (2010) \\
\hline Woodward & - & Gertrude M. & Turner et al. (2010) \\
\hline Woodward & - & Alice B. & Turner et al. (2010) \\
\hline Workman & MacRobert & Rachel & Hulbe et al. (2010); Ogilvie and Harvey (2000); Burek (2009) \\
\hline Wyckoff & & Dorothy & Philadelphia Area Archives Research Portal (2019); Ogilvie and Harvey (2000) \\
\hline Wynne Edwards & Reid & Eleanor M. & Ogilvie and Harvey (2000) \\
\hline Yakobevna & Polubarinova-Kochnia & Pelageya & $\begin{array}{l}\text { Proffitt (1999); Ogilvie and Harvey (2000); Zlotnik and Emikh (2007); anony- } \\
\text { mous (2009) }\end{array}$ \\
\hline Yelverton & Hastings & Barbara & $\begin{array}{l}\text { Creese and Creese (1994); Ogilvie and Harvey (2000); TrowelBlazers - Barbara } \\
\text { Hastings (2019) }\end{array}$ \\
\hline Zaniewska & Chlipalska & Eugenia & Eyczewska (1981); Ogilvie and Harvey (2000) \\
\hline Zenaki & & Silvia & Ogilvie and Harvey (2000) \\
\hline \multirow[t]{7}{*}{ Zlatarovic } & & Rely & Ogilvie and Harvey (2000) \\
\hline & Amalitskiya & Anna P. & Ogilvie and Harvey (2000) \\
\hline & Cole & Mary L. & Burek and Kölbl-Ebert (2007); Creese and Creese (1994) \\
\hline & Kablik & Josephine E. & Ogilvie and Harvey (2000) \\
\hline & Mirchink & Maria E. & Ogilvie and Harvey (2000) \\
\hline & Selenka-Heinemann & Margarethe L. & TrowelBlazers - Margarethe Lenore Selenka (2019) \\
\hline & Talbot & Jane & Creese and Creese (1994) \\
\hline
\end{tabular}

\subsection{The first challenge - discrimination during studies}

The difficulties for women in earth sciences started with structural discrimination; during the 19th century and the beginning of 20th century, many universities were still closed to women. Due to this, of the 165 women for whom we had information on this subject, 37 had no formal academic education. They learned in the field by themselves thanks to textbooks and/or while working with their husbands or other women. From 1869 British universities started granting access to women but not necessarily awarding degrees, like Oxford and Cambridge (until 1923 partially and 1948 fully; Fraser and Cleal, 2007, citing Schmid, 2001). From 1904 to 1907 , women studying there went to Trinity College in
Dublin to get degrees (they were called "steamboat ladies"; Hulbe et al., 2010). And in reaction to universities refusing to open their doors to women, some women-only colleges were founded: in the United Kingdom Bedford College as soon as 1849; Newnham College in Cambridge in 1871 (see e.g. Burek and Higgs, 2007); and Royal Holloway in 1886 and Westfield in 1882, both in London (Fraser and Cleal, 2007; Burek, 2007). In the USA Barnard College was founded in 1889 after Columbia refused to admit women, along with Bryn Mawr in 1885 (where the department of geology was developed by Florence Bascom), Wellesley in 1870 and Smith in 1875. In Russia, the Moscow Higher Course for Women (later part of Moscow University) was opened in 1900. Other 
Table 2. Some of the major contributions female geologists realised and contributed to in the 19th century and up to the 1960 s.

\begin{tabular}{|c|c|c|c|}
\hline Subject & Contribution & Year & Scientist(s) \\
\hline Atmospheric chemistry & $\begin{array}{l}\text { First published paper to demonstrate enhanced absorption of so- } \\
\text { lar radiation by } \mathrm{CO}_{2} \text { and water vapour (through laboratory ex- } \\
\text { periments), causing an increase in temperature, and to speculate } \\
\text { on the potential for climate warming: "an atmosphere of that } \\
\text { gas would give to our Earth a high temperature; and if, as some } \\
\text { suppose, at one period of its history, the air had mixed with it a } \\
\text { larger proportion than at present, an increased temperature from } \\
\text { its own action as well as from increased weight, must have nec- } \\
\text { essarily resulted" }\end{array}$ & 1856 & Eunice Newton Foote \\
\hline Atmospheric physics & $\begin{array}{l}\text { First scientist to write about the importance of solar radiation to } \\
\text { the energy balance at earth's surface }\end{array}$ & 1848 & $\begin{array}{l}\text { Mary Fairfax } \\
\text { Somerville }\end{array}$ \\
\hline Cryosphere & $\begin{array}{l}\text { Comparing old and new maps, she stated "possibilities of } \\
\text { glacial retreat should not be overlooked" }\end{array}$ & 1932 & Louise Arner-Boyd \\
\hline Economical geology & Specialist of marble in Roman architecture & 1907 & Mary Winearls-Porter \\
\hline Engineering geology & $\begin{array}{l}\text { A pioneer of engineering geology; feasibility studies for eight } \\
\text { bridges }\end{array}$ & 1920 s and 1930 s & Ellen Louis Mertz \\
\hline \multirow[t]{2}{*}{ Geochemistry } & $\begin{array}{l}\text { Perfected detection methods of minerals in water; } \\
\text { new methods for uranium and thorium analyses }\end{array}$ & $\begin{array}{l}1920 \mathrm{~s} \\
1940 \mathrm{~s}\end{array}$ & Margaret Foster \\
\hline & $\begin{array}{l}\text { New method to measure radioactive gases in air samples; } \\
\text { showed that precipitation lowered the quantity of radium em- } \\
\text { anation (radon) in the air }\end{array}$ & $1920 \mathrm{~s}$ & Rely Zlatarovic \\
\hline Geophysics & $\begin{array}{l}\text { Developed a highly sensitive electrometer to investigate ra- } \\
\text { dioactivity in rocks and sea water }\end{array}$ & $1940 \mathrm{~s}$ & Hermine Folmer \\
\hline Historical geology & $\begin{array}{l}\text { Resolved the origin of Britain's Malvern Hills (proving her } \\
\text { brother right and Sir Murchison wrong): igneous rocks first and } \\
\text { Devonian sediments later, proved through field work on an out- } \\
\text { crop; conglomerate with fragments of the igneous hills at the } \\
\text { base of Silurian, which became known as Miss Phillips' Con- } \\
\text { glomerate }\end{array}$ & 1842 & Anne Phillips \\
\hline Hydrodynamics & $\begin{array}{l}\text { Major role in hydrodynamics (including groundwater motion) } \\
\text { and meteorology theory }\end{array}$ & 1930s-1950s & $\begin{array}{l}\text { Pelageya Yakobevna } \\
\text { Polubarinova-Kochnia }\end{array}$ \\
\hline Marine geology & $\begin{array}{l}\text { Produced and contributed to sea bed maps (Barents, Atlantic, } \\
\text { etc.) and Antarctic atlas }\end{array}$ & $1960 \mathrm{~s}$ & Maria Klenova \\
\hline Mineralogy & $\begin{array}{l}\text { Rare form of quartz discovered named "cotterite" after her by } \\
\text { Prof. Harkness }\end{array}$ & 1876 & E. Cotter \\
\hline Palaeontology & Early and extensive fossils collection, catalogue & 1831 & Etheldred Benett \\
\hline $\begin{array}{l}\text { Vertebrates } \\
\text { palaeontology }\end{array}$ & Founder of palaeoneurology & $1920 \mathrm{~s}$ & Tilly Edinger \\
\hline $\begin{array}{l}\text { Palaeontology: } \\
\text { Paleozoic }\end{array}$ & Taxonomy of gastropods & $1902-1933$ & Jane Donald Longstaff \\
\hline $\begin{array}{l}\text { Palaeontology: } \\
\text { Mesozoic }\end{array}$ & $\begin{array}{l}\text { First ichtyosaur ever discovered or at least officially described, } \\
\text { with her brother; two plesiosaurs: one nearly complete in } 1823 \\
\text { and another in 1830; belemnite with its inker bag (1828), } \\
\text { pterosaur (1828), Squaloraja (1829) }\end{array}$ & $1811-1829$ & Mary Anning \\
\hline \multirow[t]{2}{*}{$\begin{array}{l}\text { Palaeontology: } \\
\text { Cenozoic }\end{array}$} & $\begin{array}{l}\text { Tertiary mammals (data from Russia, Western Europe and } \\
\text { America), especially ungulate and proboscidians (including } \\
\text { Russian mastodons); genetic lines; description of complete fau- } \\
\text { nas }\end{array}$ & $1890 \mathrm{~s}$ & $\begin{array}{l}\text { Maria Gortynskaia } \\
\text { Pavlova }\end{array}$ \\
\hline & $\begin{array}{l}\text { Expedition to the Dominican Republic; descriptions of fossils, } \\
\text { including more than } 400 \text { new species; foundation for multi- } \\
\text { disciplinary research to understand evolutionary change in the } \\
\text { Caribbean, from the Miocene era to the present day }\end{array}$ & 1916 & Carlotta Maury \\
\hline $\begin{array}{l}\text { Palaeontology: } \\
\text { Quaternary }\end{array}$ & Co-founder of modern archaeozoology & $1900 s-1930 s$ & Dorothea Bate \\
\hline Palynology & Pollen analysis for glaciation studies & 1930s-1940s & Kathleen Blackburn \\
\hline
\end{tabular}


Table 2. Continued.

\begin{tabular}{|c|c|c|c|}
\hline Subject & Contribution & Year & Scientist(s) \\
\hline \multirow[t]{3}{*}{ Palaeobotany } & $\begin{array}{l}\text { Anatomy of reproductive structures by cutting of sections of } \\
\text { petrified plants: her evolution model remains one of the most } \\
\text { likely explanations }\end{array}$ & 1904 & Margaret Benson \\
\hline & $\begin{array}{l}\text { Model formation of coal ball taphonomy still widely accepted } \\
\text { today; coal petrography, terminology still used today; Carbonif- } \\
\text { erous coal forest as complex ecosystems }\end{array}$ & $1903-1935$ & Marie Stopes Roe \\
\hline & $\begin{array}{l}\text { Use of fossil plants to define biostratigraphic units, which was } \\
\text { then new (done with fauna but not flora before) }\end{array}$ & 1930s & Emily Dix \\
\hline Petroleum geology & $\begin{array}{l}\text { Wrote the paper "Sequence and oil bearing zones Gulf Coast } \\
\text { with microfossils", proving foraminifers could be used to date } \\
\text { strata and thus estimate the likelihood of petroleum; see also } \\
\text { Sects. } 4.2,6.2 \text { and } 7\end{array}$ & 1925 & $\begin{array}{l}\text { Esther Richards } \\
\text { Applin, Alva Ellisor, } \\
\text { Hedwig Kniker }\end{array}$ \\
\hline $\begin{array}{l}\text { Petrology: } \\
\text { metamorphic rocks }\end{array}$ & $\begin{array}{l}\text { Description of serpentinite mineralogy (using Anglesey, as one } \\
\text { of her case studies associated metamorphism accompanying } \\
\text { rocks of Precambrian age), which also advanced the under- } \\
\text { standing of metamorphism }\end{array}$ & $1890 \mathrm{~s}$ & Catherine Raisin \\
\hline \multirow[t]{2}{*}{$\begin{array}{l}\text { Petrology: igneous } \\
\text { rocks }\end{array}$} & $\begin{array}{l}\text { Theory of "granitisation" to explain the formation of granite, } \\
\text { which was eventually proved incorrect but provoked much re- } \\
\text { search in this poorly understood field }\end{array}$ & 1940 s & Doris Livesey Reynolds \\
\hline & $\begin{array}{l}\text { Specialist of crystalline rocks of the Piedmont, between the Ap- } \\
\text { palachian range and Atlantic coastal plain }\end{array}$ & $1890 \mathrm{~s}-1930 \mathrm{~s}$ & Florence Bascom \\
\hline Glacial geomorphology & $\begin{array}{l}\text { Detailed geomorphology around the Vatnajökull (Iceland; pub- } \\
\text { lications cited in The Glaciers of Iceland, Helgi Björnsson's } \\
2017 \text { book; Björnsson, 2017) and Spitzebergen }\end{array}$ & 1960 & Emmy Todtmann \\
\hline \multirow{4}{*}{$\begin{array}{l}\text { Regional geology and } \\
\text { mapping }\end{array}$} & Produced the map of Anglesey (Wales, UK) with her husband & $1890 s-1920 s$ & Annie Barnard Greenly \\
\hline & Geology of Cornwall & $1930 s-1960 s$ & Eileen Hendricks \\
\hline & First major work on Ottawa regional geology & $1920 s-1940 s$ & Alice Wilson \\
\hline & $\begin{array}{l}\text { Mapping of Pennsylvania, Maryland and New Jersey (USA) for } \\
\text { the United States Geological Survey }\end{array}$ & $1890 \mathrm{~s}-1930 \mathrm{~s}$ & Florence Bascom \\
\hline \multirow[t]{3}{*}{ Stratigraphy } & $\begin{array}{l}\text { Classification of graptolites, which is useful for stratigraphy } \\
\text { and without which the establishment of the Ordovician period } \\
\text { would have been less acceptable; their monograph is still a ref- } \\
\text { erence; see also Sects. } 6.2 \text { and } 7\end{array}$ & $1910-1918$ & $\begin{array}{l}\text { Ethel Wood Shakespear } \\
\text { and Gertrude Elles }\end{array}$ \\
\hline & $\begin{array}{l}\text { Welsh stratigraphy of early Paleozoic periods, often using grap- } \\
\text { tolites as stratigraphic indicators; see also Sects. } 6.2 \text { and } 7\end{array}$ & $1890 \mathrm{~s}-1920 \mathrm{~s}$ & $\begin{array}{l}\text { Margaret Crosfield and } \\
\text { Ethel Skeat Woods }\end{array}$ \\
\hline & $\begin{array}{l}\text { Dolomite maps and stratigraphy, classifying for this purpose } \\
\text { many coral species based on microscopic observations (a first) }\end{array}$ & $1890 \mathrm{~s}-1930 \mathrm{~s}$ & Maria Ogilvie Gordon \\
\hline $\begin{array}{l}\text { Seismology and the } \\
\text { earth's structure }\end{array}$ & $\begin{array}{l}\text { Discovery of the earth's solid inner core and liquid outer core; } \\
\text { improvement of techniques used to analyse measurements from } \\
\text { various seismographic observatories }\end{array}$ & 1936 & Inge Lehmann \\
\hline \multirow[t]{2}{*}{ Structural geology } & $\begin{array}{l}\text { Structural geology and sedimentary sequences of the Front } \\
\text { Range of the Rockies in Colorado, useful for both oil compa- } \\
\text { nies and the understanding of mountain building }\end{array}$ & $1920 s-1940 s$ & Margaret Fuller Boos \\
\hline & $\begin{array}{l}\text { Structural geology (folds and faults) and cross section interpre- } \\
\text { tation of the Clwydian Range and its erosion }\end{array}$ & 1925 & $\begin{array}{l}\text { Margaret Crosfield and } \\
\text { Ethel Skeat Woods }\end{array}$ \\
\hline Teaching & $\begin{array}{l}\text { Introduced field as a major tool for teaching both geology and } \\
\text { geography }\end{array}$ & $1900 s-1920 s$ & Zonia Baber \\
\hline
\end{tabular}


institutions were also progressive and allowed quite a few women to study, such as University College London (awarding full degrees to women from 1878; Fraser and Cleal, 2007). These institutions were, however, not the only ones; many women also found their ways through other universities, though they sometimes had to try different ones, like Maria Ogilvie Gordon, who was refused admission at Berlin University in 1891 but then managed to enrol at Munich University. The positive consequences of the progressive opening of universities' doors for women's access to research activities are evident in the number of papers by British female geologists; as many (about 120) were published from 1885 to 1900 as from 1800 to 1884 (Creese and Creese, 1994).

In the 1920 s most remaining universities started admitting women when female education started to be encouraged by many governments, at least in Europe, with different motivations, including the lack of men following WWI (Hulbe et al., 2010; Gries, 2017) and the Soviet Revolution in the USSR.

Even when access to universities had been gained, attending them could be quite problematic; the cases of Florence Bascom, Evgenia Solomko Viktorovna and Maria Ogilvie Gordon are emblematic. All born at the beginning of the 1860s, studying in different countries (USA, Switzerland and Germany), they all encountered the same type of obstacles. During her $\mathrm{PhD}$, Florence Bascom was made to sit behind a screen during classes so as not to "distract" her male classmates. Similarly, Evgenia Solomko Viktorovna and Maria Ogilvie Gordon had to take some classes in a different room than the male students.

\subsection{Discrimination in the workplace}

Finding a job or another way to do research was not easy. At the time universities were hardly accessible to female students; they were even less inclined to hire them as researchers and teachers. When women started to have master's degrees and PhDs, they were still denied access to jobs. This lack of career opportunities might have led women away from studying their subject. Tilly Edinger opted for zoology after beginning in geology, thinking getting a job as a biologist would be easier. She finally mixed both disciplines and created a whole new domain. Silvia Zenaki changed her subject to botany because it was too difficult to get a job in geology. Several palaeobotanists did the same, turning or going back to botany after a few studies on fossil plants (see Sect. 6.2 "Male mentors"). Some persisted without merited success. For example, Marjorie O'Connell, after several 2or 3-year contracts from 1913 to 1918 at several universities, was hired at the American Museum of Natural History. She was, however, paid much less than men and received no other financial support. She had to quit the museum to work in a bank instead. After her marriage she did social work but never came back to science. Eileen Hendricks seemed to have been very discouraged as well; though she did much work for the British Geological Survey and tried to get hired, she only found temporary employment for the photo catalogue.

The difficulties to find a job are also reflected by the fact that women who received university prizes or scholarships often did not have a career afterwards; for example, of the 17 women awarded Sydney University's prize for geology from 1892 to 1925 , only 3 had an academic career or publications afterwards: Dorothy Powell and Marie Bentivoglio in 1916 and Ida Brown Browne in 1922 (Turner, 2007, citing Branagan, 1974).

Structural discrimination was frequent in employment and research activities. Since universities, associations and societies had been closed to women for a long time, it complicated their work, especially the communication of their results and their access to the results of others as well as to scientific discussions. Mary Anning and Ida Slater Lees were not allowed to communicate their papers themselves at the Geological Society of London; male colleagues did it for them. The Geological Society, created in 1807, admitted female members only from 1919, just in time to avoid doing it because they were forced to by law (Burek, 2009). The Geologists' Association was an exception as it was open to women from its start in 1857 , but it was a much more "amateur" society (Burek, 2009). Many institutions imposed single status on their female employees; if they got married they had to resign. This was the case at the British Geological Survey (up to 1975; Rossiter, 1982), and thus staying unmarried, e.g. for Eileen Guppy, was not necessarily a choice. In Australia a similar rule in the public service prevailed until 1966 (Turner, 2007). The universities in the USA did not apply such a rule, but as they forbade employing couples up until the 1960s, husbands were generally employed but not their wives (Rossiter, 1982). This is the reason why Eleanora Bliss Knopf never worked at Yale.

Some unwritten rules were so common they could be considered structural as well. The cases of non-credited contributions were regular, imposed by many husbands on their wives (see Sect. 6.1 "Husbands") but also by colleagues. Georgina King claimed that her ideas had been plagiarised by male scientists in Sydney, and Alva Ellisor, Esther Applin and Hedwig Kniker were ignored by Edgar Owen in his Trek of the Oil Finders, preferring four men who had used these three women's work to complete their own. At least one case of what would now be called harassment - isolation, endless refusal of promotion, etc. - is documented with what Alice Wilson experienced during most of her career at the Canadian Geological Survey. She quietly persisted until her final recognition, which came after external pressure.

In a few known cases, women saw their work contested on a sheer sexist basis. The most emblematic case is the one of Maria Graham Callcott, whose competence as a geological observer was attacked by G. Greenough, the president of the Geological Society. The attacks generated international controversy within the geological community. She had witnessed an earthquake and its consequences in Chile in 1822, 
including the uplift of major blocks of land, and had written about it in one of the earliest accurate and detailed reports of the effect of seismic activity. This report was used by Charles Lyell in his work Principles of Geology in 1830. Much later, in 1921, Esther Richards Applin was first ridiculed by older male geologists for her hypothesis that foraminifera could be used to date strata and thus locate potential oil deposits. Along with two other women she proved herself right a few years later (see Sect. 3 "Some major contributions").

Women faced harsh consequences. In terms of numbers, female geologists represented only $3 \%$ to $4 \%$ of all geologists in the USA in the 1920s and 1930s (Rossiter, 1982), which is comparable but less than the proportion of women in all sciences (5\% to $7 \%$; Rossiter, 1982). In addition to abandoning science (see previous and next paragraphs), some testimonies of psychological consequences can be found; the low numbers are probably highly due to the huge amount of private correspondence that disappeared or that was never traced. The lack of recognition gave Maria Ogilvie Gordon, among others, a hard time. She finally obtained some recognition, notably the Lyell Medal in 1932, but that was late in her life (she died in 1939). One case of a breakdown clearly related to overwork and a hostile work environment is the mental and physical breakdown of Winifred Goldring in 1926, who fortunately recovered and resumed her career. As for Emily Dix's breakdown, tension and exhaustion cumulated during the war was the primary cause of her internment in a mental institution from 1945, but the sexist undermining of her studies and work cannot be ruled out. She never recovered.

\subsection{Family pressure}

Parental pressure could delay the fulfilment of a vocation; Luella Owen had to wait for her father's death in 1890 to do her research on caves. Of course many must have had a craving they never had the opportunity to pursue. Careers could start late and were also too often cut short. When women bore the weight of taking care of children or other members of the family, there would be gaps in their research activities, as was the case with Katherine Fowler-Billings from 1942 to 1949 and 1956 to 1960 as well as Eileen Hendricks from 1921, when she put her career on hold to take care of her mother. Or they would have less time to conduct these research activities: Mary Morland Buckland, in addition to looking after her children, had poor health due to pregnancies; Barbara Yelverton Hastings' many pregnancies and social obligations forced her to stay home and to restrict her work in terms of location and time; Kathleen McInerny Sherrard supported her family after her father's death; and Pelageya Yakobevna Polubarinova-Kochnia left her job to raise her daughters but stayed active professionally. Maria Mirchink completely left scientific work after her children were born.

Marriage on its own could slow down women's careers considerably, from moving geographically to follow their husbands' jobs, which complicated their own careers, to great slowdown in research. Eleanora Bliss Knopf followed Adolph Knopf to Yale and later to Stanford but still managed to work for the United States Geological Survey (USGS) and give private instruction. Agnes Robertson Arber resigned to follow her husband to Cambridge before finding a new job 2 years later in 1911. Pelageya Yakobevna PolubarinovaKochnia changed jobs in 1935 as the family moved for her husband's job. Janet Dingwall Harrison had a large geology career before marrying the geologist J. V. Harrisson, whom she followed to Oxford, and managed only informal work after that. Helen Plummer Skewes delayed her master's degree by 10 years to work part-time for her husband. For more women, marriage even made them stop research completely: Evgenia Solomko Viktorovna in 1888, Ida Slater Lees in 1912, Catherine Drummond-Smith Cotton in 1919, Edith Bolton Helsby in 1930, Hertha Sieverts Doreck in 1936 and Ida Brown Browne in 1950. Finally, there is the tragic example of Eliza Gordon Cumming, who died after giving birth for the 13th time, while she was looking forward to going back into the field. And these are women who already had a scientific or a research activity; we should keep in mind that female students were not that rare in the late 19th century, but many got married and stopped their studies before starting research (Turner, 2007).

\subsection{Multiple types of discrimination}

Some women scientists experienced not only sexism but also other kinds of discrimination. Marguerite Thomas William was African-American, and the fact that she received no research opportunity after her $\mathrm{PhD}$ but a teaching position only was most probably rooted in racist as well as sexist prejudices. Tilly Edinger's letters from 1933 to 1938 tell of the difficulties of maintaining a scientific career for a disabled Jewish woman in Nazi Germany. She had to leave the country in 1939, to the United Kingdom and then the United States, where American colleagues found a position for her. She was part of the exile of Jewish scientists fleeing Nazi repression including well-known men (physicist Albert Einstein, mathematician Kurt Friedrich Gödel, mathematician and physicist John von Neumann) and lesser-known women (mathematician Emmy Noether and physicist Lise Meitner; Chazal, 2006).

Sexual harassment and other forms of masculine violence towards women are not documented for any of the 210 women of this list, which does not mean it did not happen; it should be kept in mind that disclosing such matters was even harder then than it is now.

Several historical events or particularities created windows of (relative) opportunities, in particular the Industrial Revolution coupled with slightly less rigid gender models in Britain, World War I and the Soviet Revolution. Out of the 210 female geoscientists identified from 1800 to 1929,85 are British; 49 American (USA); 21 Russian/USSR; 13 Aus- 
tralian; 24 from Western Europe, excepting the United Kingdom; 8 from Eastern Europe; 5 from northern Europe; and 5 from Canada, South Africa or Argentina. Of course data availability and translation in English and French (the languages I can read) might have an impact on these proportions. Beyond that, Britain's first position can be explained by the early development of the Industrial Revolution there and the concomitant development of modern geology. Indeed in the 19th century, geology was a scientific domain dominated in numbers by the British (Creese and Creese, 1994). This particularity, coupled with gender role models not as rigid as in continental Europe in the first half of the 19th century, allowed more women to have careers in geology in Great Britain than anywhere else (e.g. Germany; Kölbl-Ebert et al., 2007; Kölbl-Ebert and Turner, 2016). To the east, the Soviet Revolution and its premises opened studies and work opportunities for women. And World War I caused shortages in the workforce, which also opened (temporary) opportunities for women.

\section{Overcoming discrimination 1: family configuration and support}

Even if undertaking studies and a scientific career meant then more than now - facing much discrimination, many women managed it, relying on at least one class or family asset. At least 35 of them were upper-class (see also Burek and Higgs, 2007), while at least 44 belonged to the middle class, and only 3 are identified as being working-class: Orra White Hitchcock, Mary Anning and Winifred Goldring. Two other familial factors seem key in overcoming the discrimination women faced by pursuing scientific studies formally or informally and then engaging in research: family openness to science and girls' education as well as single life.

One key factor in overcoming sexist discrimination was parental or family support. At least 44 of the 210 female geologists listed had a scientist among their close relatives. The fathers of 27 of them were professional scientists: Mary Andrews' father was a chemist and vice president of a university; Tilly Edinger's father was a neurobiologist; and at least five were naturalists, including two fossil collectors the fathers of Mary Anning and Elizabeth Anderson Gray and one archaeologist, the father of Marie Stopes Roe. Four of them had scientist mothers: Charlotte Hugonin Murchison, Delvalle Lowry Varley, and Alice and Edith Gray. Both Rachel Workman MacRobert's parents were scientists (she was the daughter of Fanny Bullock Workman). Moreover, four grew up in the proximity of scientist relatives: Etheldred Benett's interest in geology was encouraged by her sisterin-law's half-brother, the botanist Aylmer Bourke Lambert; Anne Phillips' uncle William Smith was the author of the first UK geological map; Grace Milne Prestwich's uncle Hugh Falconer was a palaeontologist; and both of Alice Wilson's older brothers were geologists. Finally, 22 had very support- ive and encouraging parents or close relatives concerning education and studies: Orra White Hitchcock's farmer father paid her tuition and then her pension, Caroline Birley was supported by her grandmother, Isabelle Peyronnet-Browne was encouraged from the age of 9 to study geology and botany, and Isabelle Fothergill Smith was sent by her parents to university like her three sisters. Some parents were so keen to educate girls like boys that they sent their daughters to progressive schools, as was the case with Margaret Chorley Crosfield and Inge Lehman. Florence Bascom's parents were both for gender equality, and her father used his position as the president of the University of Wisconsin-Madison to open the institution to women, 2 years before his daughter entered it. In total, at least 57 of the 210 women geologists identified, thus more than one-fourth, had a very stimulating and/or supportive environment concerning science and education. In two cases family tragedies opened new opportunities: Katherine Fowler-Billings' parents died during her studies, leaving her both rich and relieved from social expectations, and Tilly Edinger's scientist father, who was unsupportive of women in science, died when she was in her early 20 s.

The absence of a husband was another factor that seemed key in the possibility of realising a scientific career. Unmarried status is certain for 63 of the women geologists identified, thus nearly a third of them. A total of 53 more were probably single as well; at least no marriage is indicated in the sources. This would increase the proportion of single women to more than half of the total. In addition, Fanny Carter Edson divorced so quickly she can be counted as single. For a few more, being widowed relatively early in life presented an occasion to finally do research (Mary Hone Smith) or to do it more freely (maybe for Maria Graham Callcott, definitely for Delvalle Lowry Varley) or on their own, thus showing they were more than their husbands' assistants (Ebba Hult de Geer).

Moreover, if 94 of the 210 were allegedly married, 27 (out of 56 for whom the age of marriage is known) married late considering the standards of the time: in their 30s for 17 women; in their 40s for Arabella Buckley Fisher, Ethel Skeat Woods, Janet Dingwall Harrison and Doris Livesey Reynolds; and in their 50s for Sydney Mary Thompson Christen, Jane Donald Longstaff, Mary Vaux Walcott, Anna Jonas Stose and Ida Brown Browne (she retired after getting married; see Sect. 4 "Discrimination").

As a consequence - and maybe also by choice - only few of them seem to have had children; of the 98 for which this information is certain, 30 (all married) had children, and 68 did not (including 11 married women; see also above Sect. 4 "Discrimination").

Staying unmarried or single for a long time was thus an opportunity to retain one's freedom regarding life's options and even often a strategy. Indeed, not being married did not necessarily mean a lack of interest in relationships and having a love life, but very often private correspondence, which 
could have filled in the blanks of their private lives, was not kept (Dominus, 2019). Marie Stopes Roe is an exception (we know of her Japanese lover). Guesses can also be made that some of the long-term friendships, collaborations and living arrangements under the same roof could have been lesbian relationships.

Other strategies were very important to carrying on with research: collaborative work in different forms, as presented in the next two parts, "Overcoming discrimination 2: in the shadow of 'great men"" and "Overcoming discrimination 3: sorority".

\section{Overcoming discrimination 2: in the shadow of "great men"}

Quite a few of the early and less early female geologists remained in the shadows of "great men".

\subsection{Husbands}

Husbands were often a pathway to research but also to appropriation, as in all sciences (Rossiter, 1993). For the female geologists getting married, if their husband was also a geologist, it could be an efficient way to get access to the field and to scientific exchanges. Wives were often field assistants and contributed illustrations to or editing (or rewriting) of their husbands' publications; sometimes work was done fifty-fifty. But equally often husbands appropriated their wives' work, more or less on purpose, by signing papers and books alone and just mentioning their wives in the acknowledgement section or in their private correspondence. Evidence of such events exists for 22 of those "wives of"; see Table 3.

The first of them is also the most emblematic: Charlotte Hugonin Murchison, without whom her husband Roderick Murchison would simply never had become a geologist. She drove him towards this subject as she was passionate about it (according to Mary Somerville, friend of the couple) and then influenced him and even supported him financially (after inheriting in 1838). Clearly her husband owed his great career (he became director of the Geological Survey of Great Britain in 1855) largely to her, from her taking notes during their field trips, collecting fossils and cataloguing their collection to illustrating his books (without being acknowledged as a co-author). Her fossil collection was also studied by other scientists like J. de Carle Sowerby and William Buckland. Palaeontology pioneer and geologist Edward Hitchcock (professor, president of Amherst College and state geologist) acknowledged the essential contributions of his wife Orra White Hitchcock to his work in his dedication of The religion of geology. Mary Morland Buckland met her husband William Buckland (geology professor at Oxford) in a coach, where she was reading Georges Cuvier. She assisted him in the field, drew illustrations for his papers and proofread them as well. He had a bias against women in science but still re- lied on her. Mary Horner Lyell never became widely known in her own right, although it is believed by historians that she likely made major contributions to her husband Charles Lyell's work. Robert Gray, who married Elizabeth Anderson Gray was supportive of her but still presented the family results under his name. What we know about Annie Barnard Greenly mostly comes from her husband Edward Greenly's autobiography. Pauline Crié Oehlert's husband Daniel Victor Oehlert simply stopped publishing after his wife's death. Mary Weston McKenny Hugues' husband Thomas McKenny Hugues, professor at Cambridge, was quite a supporter of women in geology, though sometimes on account of sexist prejudices (see Sect. 6.2 below). The husband and wife authored papers together, but she had no academic position of her own. Helene Stevens Walcott and Mary Vaux Walcott had the same husband, from 1888 to Helene Stevens Walcott's death in 1911 and from 1914 to his death in 1927, respectively. Charles Doolittle Walcott, a palaeontologist and secretary of the Smithsonian Institution, was the discoverer of the Burgess Shale; Mary had an active part in his projects. Ebba Hult de Geer's contributions to her husband's work are overlooked; they worked closely together, but he signed most papers alone. It should be noted that he proposed to her and offered her a job at the same time. Helen Plummer Skewes reduced her own workload to work part-time for her husband after they got married (editing, preparing drawings, checking data). Even if not in the shadow of their husbands, for some women scientists being married was a drawback for their own career as childcare responsibilities fell to them only, or the husbands' jobs dictated geographical moves (see Sect. 4 - Discrimination).

It should also be said that a few women had fully supportive partners without any ambiguity or priority given to the husband's career or child support by the mother only. It is interesting that for four out of eight women in this case, marriage took place really late in the women's lives: Arabella Buckley Fisher; Sydney Thomson Christen; Jane Donald Longstaff; and Anna Jonas Stose, with George Stose, a USGS stratigrapher who came and worked with her in the Appalachian mountains. The other four who had unambiguously supportive husbands were Josephine Kablik with Adalbert Kablik, pharmacologist and zoologist as well as supporter and collaborator; Fanny Bullock Workman with William Hunter Workman, who collaborated closely; Maria Ogilvie Gordon with John Gordon, who accompanied her and the children in the field; and probably Ludmila Kaplanova Slavikova with F. Slavik, a mineralogist, who worked together and then resisted against the Nazis during WWII. Three had two husbands with very different luck: until 1807, Mary Fairfax Somerville had a husband who did not allow her to pursue science and then a supportive one from 1812, but she was still in charge of the house and the children. Sarah Bowdick Lee was first married to a naturalist, with whom she travelled to Africa and collaborated with Cuvier. Things were very different with her second husband; 
Table 3. Female geologists who worked with their husbands and stayed in their shadow (by date of birth).

\begin{tabular}{|c|c|c|}
\hline Wife & Year of birth & Husband \\
\hline Charlotte Hugonin Murchison & 1788 & $\begin{array}{l}\text { Roderick Murchison, director Geological Survey of } \\
\text { Great Britain in } 1855\end{array}$ \\
\hline Mary Ann Woodhouse Mantell & 1795 & Gideon Mantell \\
\hline Orra White Hitchcock & 1796 & $\begin{array}{l}\text { Edward Hitchcock (professor, president of Amherst } \\
\text { College, state geologist) }\end{array}$ \\
\hline Mary Morland Buckland & 1797 & William Buckland (professor, Oxford) \\
\hline Mary Horner Lyell & 1808 & Charles Lyell \\
\hline Elizabeth Cary Agassiz & 1822 & Louis Agassiz \\
\hline Elizabeth Anderson Gray & 1831 & Robert Gray \\
\hline Margaret Adamson Hobson & 1837 & EC Hobson \\
\hline Annie Barnard Greenly & 1852 & Edward Greenly \\
\hline Pauline Crié Oehlert & 1854 & Daniel Victor Oehlert \\
\hline Mary Weston McKenny Hugues & 1860 & Thomas McKenny Hugues (professor, Cambridge) \\
\hline Anna P. Amalitskiya & 1861 & V. P. Amalistkiya (professor, Warsaw University) \\
\hline Blanche Vernon Cole & 1862 & Grenville Cole (he was also her former teacher) \\
\hline Hester Pengelly Julian & 1865 & F. Julian \\
\hline Helene Stevens Walcott (1888 to 1911) & 1868 & Charles Doolittle Walcott \\
\hline Mary Vaux Walcott (1914 to 1927) & 1860 & Charles Doolittle Walcott \\
\hline Agnes Robertson Arber (at least for her palaeobotany work) & 1879 & E. A. Newell Arber \\
\hline Lotte Adametz Kittl & 1879 & Ernst Kittl (Vienna Natural Museum) \\
\hline Ebba Hult de Geer & 1882 & Gerard de Geer \\
\hline Marta Cornelius-Furlani & 1886 & Hans Peter Cornelius \\
\hline Mabel Crawford-MacDowall Wright & $?$ & William Bourke Wright \\
\hline Helen Skewes Plummer & 1891 & Frederick Byron Plummer (University of Texas) \\
\hline
\end{tabular}

she then mostly did popularisation writing. Barbara Yelverton Hastings' second husband was supportive.

In seven cases collaboration is evident, but their conditions are unknown: Olga Mikhailovna Shubnikova; Emma Hüther Richter with palaeontologist Rudolf Richter; Margaret Fuller Boos; Esther Richards Applin; Dorothy Kemper Palmer with palaeontologist Robert Palmer; Katherine Fowler-Billings with her second husband, geologist M. P. Billings; and Mildred Adams Fenton, who signed papers and books with Carroll Lane Fenton, though only he had a doctoral degree and academic positions.

And in 13 cases there is evidence of neither abuse nor support: Delvalle Lowry Varley, Grace Milne Prestwich, Maria Gortynskaia Pavlova, Eleanor Wynne Edwards Reid, Elisabeth Tschernaieff Jérémine, Olga Shirokobrumov Tumanskaya, Marguerite Thomas Williams, Katherine Van Winckle Palmer, Dollie Radler Hall, Kathleen McInerny Sherrard, Doris Livesey Reynolds Holmes, Laura Lane Weinzierl and Henderina Klaassen Scott.

Seven women, although not wives, had clear positions as secretaries or assistants and were sometimes paid for it: Anne Phillips to her brother John Phillips, an Oxford professor who named the major eras (Palaeozoic, Mesozoic, Cenozoic); Grace Prestwich Milne as assistant and secretary to her uncle Hugh Falconer (1858-1965); Arabella Buckley Fisher, Charles Lyell's long-time secretary, from 1864 to his death in 1875; Eileen Guppy as scientific assistant to the British
Survey's directors; Maria Tsvetaeva as assistant to Sergei Nikitim, including field work, for over 20 years; Igerna Sollas, who looked after her father's house for over 20 years, from 1913, and collaborated with him on internal structures of fossils; and Madeline Munro, assistant to Professor Garwood (she identified most of his palaeontological material). Finally, two women were consulted regularly by William Buckland: Jane Talbot and Mary Cole.

The women geologists who sold the fossils they found or their illustrations to colleagues for a living often found themselves in the same situation, shadowed by men they worked for or with, mostly for a lack of a paid academic position. Gertrude Woodward and Alice Woodward were professional illustrators. Three "wives of" were also illustrators for other scientists: Orra White Hitchcock, Mary Morland Buckland (for Georges Cuvier and William Conybeare) and Lotte Adametz Kittl. Their illustrations were scientific works, but they hardly got lasting recognition for that.

Several women discovered, described and catalogued important fossils, but men published about these fossils and named them. This was the case for Etheldred Benett; Mary Hone Smith; Eliza Maria Gordon Cumming; Mary Morland Buckland (her sponge fossils described by Louis Agassiz and Charles Lyell); Mary Anning, despite her precise anatomical understanding (descriptions published, for example, by Conybeare for the ichthyosaur and plesiosaur and Buckland for the pterodactyl); Elizabeth Anderson Gray (published 
by Charles Lapworth and others); and Caroline Birley and Louisa Copland (publication of the findings that they collected and Caroline Birley catalogued by Richard Bullen Newton and Henry Woodward, keeper of geology at the British Museum, who named three after Birley and Copland).

At least a few relationships with male colleagues seemed devoid of all appropriation or ambiguity: Maria Gortynskaia Pavlova and American palaeontologist Henry Fairfield Osborn; Maria Ogilvie Gordon and climber Josef Kostner, who taught her to climb and went with her in the field; Anna Missuna and Sokolov, who were both friends and collaborators; and Josie McGlamery and Walter Jones, also friends and collaborators (he actually helped her get a position).

\subsection{Male mentors}

Support of academic mentors existed and could also be decisive, and it was sometimes fair but also often based on sexist prejudice.

Some men made no difference in the way they mentored men and women; it seems like it was the case for Luella Owen, who was encouraged by three male geologists to publish, and for Florence Bascom, Maria Ogilvie Gordon and Elizabeth Jérémine Tschernaieff, each encouraged by several male mentors. The mentoring and support of male palaeobotanists FW Oliver (University College London), WH Lang and DH Scott seem to have been of that sort (Fraser and Cleal, 2007). Coupled with the opportunities given by some colleges, during the first half of the 20th century more than a third of British palaeobotanists working on Carboniferous plants were women (Fraser and Cleal, 2007). Many of them developed innovative ideas and techniques and had full careers. Marie Stopes Roe, Isabel Cookson and Henderina Klaassen Scott (working with her husband) worked in palaeobotany, while the following worked in botany: Margaret Benson (head of department), Agnes Robertson Arber, Isabel Peyronnet-Browne (maybe informally), Winnifred Brenchley (head of department), Ethel de Fraine and Grace Wigglesworth. Botany counted more women than any other scientific domain before 1950 (Ogilvie and Harvey, 2000) as it was probably considered more compatible with feminine stereotypes than other sciences.

For 12 cases, I found no clear evidence of either fairness or ambiguity in the male-mentor-female-mentee relationship.

Mentoring based on sexist prejudices is largely documented. The "Newnham Quartet" of palaeontologists is a typical case. It was the collective nickname given to women who studied the Paleozoic rocks of Wales: Margaret Chorley Crosfield, Ethel Skeat Woods, Ethel Wood Shakespear and Gertrude Elles (and a few others; see Sect. 7 "Overcoming discrimination 3: sorority"). They were studying at Newnham College, Cambridge. Professors McKenny, Marr and Lapworth recruited them in the 1880s to study Paleozoic rocks in Wales, especially to validate Lapworth's 1879 proposition to add the then new Ordovician period to solve the Silurian-Cambrian limit problem. To achieve this the three male professors considered field data necessary but found collection to be time-consuming and perhaps dull.

Lapworth reputedly said "one qualification for the task of monograph compilation then, was a capacity for drudgery" (Gould, 1998, cited in Burek, 2008), which is why they asked female students to take care of it. Burek and Malpas (2007) commented that "it was considered suitable and appropriate work for females and required great patience and perseverance." These women made a career out of this "unsexy" field work, and some of their papers became lasting references, e.g. the monograph on graptolites by Gertrude Elles and Ethel Wood Shakespear (Elles and Wood, 1910-1918) or Margaret Chorley Crosfield and Ethel Skeat Woods' work used as the basis for the British Geological Survey map of the Carmarthen area (more on their relationships in Sect. 7 "Overcoming discrimination 3: sorority"). Support and hiring based on sexism could thus sometimes turn in the favour of the hired women because they took the chance.

At least one other case of recruitment based on sexism exists in geology: the one of female micropalaeontologists working for petroleum companies in the 1920s in the USA. The combination of first the engagement of the USA in WWI in 1917, leading some men to leave companies to join the army (Gries, 2017), and then a boom in the 1920s and 1930s in the oil industry (Rossiter, 1982) opened opportunities for women. They were paid much less than men (Gries, 2017), which is a classic factor in the decision of hiring women, though in the Newnham Quartet case mentioned above it is not clear it happened. Following the discovery of the usefulness of microfossils to date and localise interesting deposits by Esther Richards Applin, Alva Ellisor and Hedwig Kniker (1925 paper; see also Sect. 3 "Some major contributions" and Sect. 7 "Overcoming discrimination 3: sorority"), a discovery which was a huge advantage for the industry, oil companies hired young women palaeontologists to examine microfossils. The samples were provided to them; thus their work was mainly looking at fossils through a microscope (Rossiter, 1982), repetitive and table-bound work that echoed the work women astronomers did at Harvard Observatory (see below). This was not considered an "occupation for a man" (Prof. Trümpy; Kölbl-Ebert and Turner, 2016). The Depression and the use of different techniques closed this opening quite rapidly (Rossiter, 1982), but most of the female petroleum geologists listed in Table 1 and the Supplement had acquired a sufficient reputation to continue their careers in oil companies.

Similar cases have existed in other sciences. In astronomy the so-called "Harvard Computers" from 1877 to 1919 , namely Henrietta Leavitt, Williamina Fleming, Annie Jump Cannon, Florence Cushman, Antonia Maury and others, were hired by Edward Charles Pickering at the Harvard Observatory to process astronomical data, the main reason being that it was repetitive clerk work with much lower pay than for men. They started as calculators, but quite a few con- 
tributed to the astronomical field and published under their own names. They are also known even more derisively as "Pickering's Harem".

In primatology, the "Trimates" or "Leakey's Angels" in the 1950s and 1960s were women chosen by Louis Leakey to study hominids in their environment: Dian Fossey, Biruté Galdikas and the now famous Jane Goodall. A fourth female researcher, Toni Jackman, had been selected to study bonobos in Africa, but the necessary financing and permits had not yet been secured before Leakey's death.

Finally, the "Human Computers" at NASA, from the 1940 s to the 1960 s, were mostly women and mostly Black, including Katherine Johnson, Dorothy Vaughan and Mary Jackson. This job was given to them because it was thought of as dull and repetitive (just as all the other cases mentioned here), and quite a few evolved from that to become engineers and computer scientists. Their story was told in the non-fiction book and fiction movie adapted from it Hidden Figures (Shetterly, 2016; Melfi, 2016).

The women whose work was shadowed and absorbed by their husbands (the "wives of") or the men they worked for as assistants, secretaries or illustrators can also be grouped in this category. They were indeed assigned tasks considered by men to be of lesser importance and/or repetitive and boring but necessary: illustrating, copy-editing, collection labelling, etc.

\section{Overcoming discrimination 3: sorority}

By sorority I mean having a woman as teacher or mentor, mentoring other women, working with other women, and also having close friendships that provide strong support. Margaret Rossiter (Rossiter, 1982) showed that first women scientists trained other women rather than hiring them from elsewhere. This often produced close relationships and sometimes "protégée chains".

Sorority is documented for 72 of the 210 women geologists identified, thus more than one-third, including 64 with other female geologists, those being minimum numbers as information is often missing.

In the early and mid-19th century women scientists seemed particularly interconnected around two figures. The first one was Mary Fairfax Somerville, who was taught mineralogy by Rebekah Delvalle Lowry, mentored the mathematician Ada Lovelace, met Charlotte Hugonin Murchison in 1817, knew Grace Milne Prestwich, was friends with Maria Graham Callcott and had her book Connexion of the Physical Sciences (1877) edited by Arabella Buckley. The second one was Mary Anning, who was close to Elizabeth Philpot despite their different class backgrounds and a 20-year age difference. Elizabeth met Mary, still a child at the time, and encouraged her to study geology and palaeontology in addition to collecting fossils. Elizabeth lived and collected fossils with her two sisters, Margaret and Mary Philpot. They were probably connected to the two Congreve sisters, Sarah and Mary. In 1835 Mary Anning also met Charlotte Hugonin Murchinson; they became good friends and may have met Mary Morland Buckland in 1839-1840 while the latter visited Axminster (only $10 \mathrm{~km}$ from Lyme Regis). Additionally, Mary Horner Lyell and Elizabeth Agassiz corresponded on subjects like the glacial geology of South America.

In the second half of the 19th century, the combination of collaborative work and friendship can be found in several duos, e.g. Jane Donald Longstaff and Elizabeth Anderson Gray, who herself mentored and worked with her two daughters, Alice and Edith. Jane and Elizabeth were friends, and Jane worked on some of Elizabeth's fossil gastropod findings. Sydney Thompson Christen and Mary Andrews as well as Caroline Birley and Louisa Copland were also both friends and co-workers. Palaeobotanist Agnes Robertson Arber worked on some of Margaret Benson's specimens, and both of them worked with botanist Ethel Sargant (Margaret and Ethel were close).

At the end of the same century, the group later called the "Newnham Quartet" formed. It may have its roots in the presence of Mary Weston McKenny Hughes on field trips (e.g. to the Malverns in 1892), which facilitated other female participation, especially by undergraduates from Newnham College: the first generation of Cambridge trained women geologists including the future Newnham Quartet. The group's next and decisive opportunity was mentoring by professors Thomas McKenny Hugues, Charles Lapworth and John Marr. They asked their female mentees to go and do what they considered time-consuming and dull field work but nonetheless necessary to have the data to validate their hypothesis that a new period should be defined between Cambrian and Silurian: the Ordovician. Margaret Chorley Crosfield, Ethel Skeat Woods, Ethel Wood Shakespear and Gertrude Elles thus went on to describe early Paleozoic stratigraphy. Ethel Wood Shakespear and Gertrude Elles joined forces on identification, classification and taxonomy of graptolites (the famous monograph published from 1910 to 1918). Margaret Chorley Crosfield and Ethel Skeat Woods cooperated first on Carmarthen area, work which became the basis of the local geological map, then on lithological and structural research on the Clwydian Range using graptolites (see also Sect. 6.2 "Male mentors" and Sect. 3 "Some major contributions"). During the latter they asked for the help of Ethel Wood Shakespear and Gertrude Elles to identify them. These four women wrote to each other, which with their papers and field books allowed scholars (e.g. Burek, 2014) to reassemble the history of their work. Mary Johnston did extensive field work with Margaret Chorley Crosfield in Shropshire. Margaret Chorley Crosfield, Ethel Skeat Woods and Mary Johnston were co-authors and also lifelong friends from 1890. Helen Drew and Ida Slater Lees also started working in 1906 on the Paleozoic of South Wales thanks to research funding. In the steps of the Newnham Quartet and with their occasional collaboration, they used 
graptolites as stratigraphic indicators. They co-authored a key paper in 1910, a work also used by the Geological Survey for the map of the area. Gertrude Elles was also a mentor at Newnham, e.g. to Dorothy Hill (too young to be on the list in Table 1 and the Supplement), and worked with Kathleen McInerny Sherrard in 1950 at the Sedgwick Museum at the University of Cambridge. The relationships all these women had with each other displayed an engaging case of female mentoring, solidarity and friendship.

In the 1920s petroleum geologists forged collaboration and helped each other: Laura Lane Weinzierl recommended Esther Richards Applin for her first job in Rio Bravo, and they co-authored a paper. Esther Richards Applin along with Alva Ellisor and Hedwig Kniker published an influential paper in 1925. The three of them shared a house for several years. Irene Crespin and Isabel Cookson worked together, and Irene Crespin's assistant, Joyce Gilbert-Tomlinson, later succeeded her (too young to be on the list in Table 1 and the Supplement). Isabel Cookson also collaborated with Gertrude Elles to identify some graptolites associated with fossils she was studying.

More occasional collaborations could also be spotted. Margaret Foster did the water analyses for one of Norah Dowell Stearns' studies. Palaeobotanists Edith Bolton Helsby and Margaret Tuck did their master's degree in collaboration. Rachel Workman McRobert had professional correspondence with Catherine Raisin and Maria Ogilvie Gordon. Ethel Dobbie Curie collaborated with C. Duncan McCallien (not on the list in Table 1 and the Supplement; too little is known about her) and Helen Muir Wood. Marie Bentivoglio and Frieda Frances Friederich (not on the list in Table 1 and the Supplement; too little is known about her) were co-authors.

At least $10 \%$ of the 210 women had a female mentor. We can distinguish mentor-mentee pairs: Elizabeth Philpot to Mary Anning, as mentioned above; Elizabeth Fisher to Winifred Goldring; Agnes Robertson Arber to Isabel Peyronnet-Browne; Fanny Workman Bullock to her daughter, Rachel Workman; and Elizabeth Anderson Gray to her two daughters Alice and Edith. In Canada, Alice Wilson received support from the Canadian Federation of University Women for graduate studies and later hired Madeleine Fritz for her field trip in Manitoba when the latter was still a student.

Florence Bascom, Catherine Raisin and Maria Gortynskaia Pavlova each mentored many students.

- Florence Bascom trained the next generation of American female geologists: Ida Ogilvie, Anna Jonas Stose, Julia Gardner, Eleanora Bliss Knopf, Mary WinearlsPorter, Isabel Fothergill Smith, Louise Kingsley, Maria Stadnichenko, Dorothy Wyckoff and Katherine Fowler Billings. In her words "I have always claimed that there was no merit in being the only one of a kind... I have considerable pride in the fact that some of the best work done in geology today by women, ranking with that done by men, has been done by my students... these are all notable young women who will be a credit to the science of geology" (letter, 1931). Some of these women later collaborated: Katherine Fowler Billings and Louise Kingsley as well as Eleanora Bliss Knopf and Anna Jonas Stose on the Appalachian range mapping; the latter seemed to have both been very bound to Julia Gardner as well. Julia Gardner later mentored Esther Richards Applin, Alva Ellisor and Winifred Goldring.

- The equivalent of Florence Bascom in Russia is Maria Gortynskaia Pavlova, who taught all Russian female geologists and palaeontologists, at least before 1917. Maria Mirchink in particular was her assistant from 1913 to 1918.

- At Bedford College, Catherine Raisin mentored Doris Livesey Reynolds, Ida Slater Lees and Helen MuirWood. She was also linked to the Newnham Quartet, especially to Mary Johnston. And many had mentees too young to be on this list: e.g. Gertrude Elles to Dorothy Hill and several others or Eleanor Wynne Edwards Reid and her assistant, Marjorie Chandler.

It should be noted that sorority was not limited to other geologists but extended to other fellow scientists. Luella Owen was strongly attached to her sisters, also scientists: folklorist Mary Alicia and ornithologist and botanist Julietta Amelia. Mary Vaux Walcott was linked to Mary Schäffer (artist and explorer) and First Lady and naturalist Lou Henry Hoover. Annie Alexander went on expeditions with Miss Wemple and Louise Kellogg, mammalogist and botanist. Dorothea Bate was invited by prehistorian Dorothy Garrod for field work in the Middle East. Mary Winearls-Porter and Dorothy Hodgkin (future Nobel Prize in chemistry) collaborated from the 1930s. Lucy Wills stayed friends with her Newnham classmate Margaret Hume in South Africa, and Kathleen Blackburn lived with her sister Dorothy. Another Dorothy, Dorothy Wyckoff, developed the history of science teaching in the 1940s along with an embryologist, Jane Oppenheimer, and corresponded with archaeologist Dorothy Burr Thompson.

\section{Focus on a new discovery: Norah Dowell Stearns}

As the literature on the first women geologists did not mention any full-time hydrogeologists, I started digging into "old" papers to see if any had a female author. I found Norah Dowell Stearns, an American hydrogeologist, who may be the first female hydrogeologist.

Even though Florence Bascom and Margaret Flynn had each published one paper on hydrogeology (Davis and Davis, 2005, note p. 128), it was not their main interest. Valentina Trizna worked briefly as a hydrogeologist in 
Moscow (1930-1932) as did Anna Nikolayevna Sokolskaya; for both of them it was only for a limited time. Pelageya Yakobevna Polubarinova-Kochnia's contribution to hydrogeology is much more important. All three of them started slightly after Norah Dowell Stearns. To complete the picture, three others had interest in water chemistry but not in its physical underground flow: Ellen Swallow Richards (pioneer in pollution studies), Nadia Sahlbom and Margaret Foster.

Norah Dowell Stearns is cited in Hydrogeology in the United States 1780-1950 only in the erratum (Davis and Davis, 2005), stating that "numerous contributions of Norah Dowell Stearns should have been included under item (j) on page 128" (i.e. in the specific section on women and hydrogeology), whereas her husband and the work they did at least partly together in Hawaii are detailed in the main text. Once again in the history of science, a married woman is omitted in favour of her husband only. Norah Dowell was born in Providence, Rhode Island, in 1891. She defended a PhD in geography in 1916 at Brown University (Dowell, 1916). From 1924 at the latest she worked for the United States Geological Survey. She was part of the Groundwater Division (Stearns, 1983), directed then by Oscar Meinzer, who is considered to have played a prominent role in the history of hydrogeology in the United States (Davis and Davis, 2005).

She probably met the geologist Harold Thornton Stearns (1900-1986) there, whom she married in 1925. They had two children: a son, Stanley Stearns (1926-2013), and a daughter, Dorothy E. Stearns (born in 1927 in California). For work, they travelled as a family through the west of the United States and then lived in Hawaii from 1930 to at least 1940. This information comes from biographies dedicated to their son, Stanley, known for drawing stamps (Brook man stamps, 2019; Russel Fink Gallery, 2019; Worth Point, 2019). You may have been a brilliant scientist, with your papers cited hundreds of times in scientific literature, and mainly be remembered because you had a son. Even her husband mentioned her only twice in his autobiography: once by her name while describing the USGS Groundwater group at the beginning of the 1920s, the second time only as "my wife" in a meaningless anecdote from 1930 (Stearns, 1983). From 1938 he mentions his second wife Claudia (not much more often than Norah).

Between 1927 and 1938, Norah Dowell Stearns was the author or co-author of at least 13 scientific publications (bibliography at the end of this section) about geology, especially Hawaiian island formation (1935a, b) and Guam (1937a, b, 1938), and hydrogeology (all other publications). She is the co-author of an important hydrological balance of the Pomperaug basin (Meinzer and Stearns, 1927), a study she took over in 1922 following the death of Arthur J. Ellis. She spent several weeks in the field and analysed glacial deposit, including sizes and porosity of tills. She also conducted work on the quantification of hydraulic conductivity (Stearns, 1927a).
She collaborated with quite a few scientists, several times with Oscar Edward Meinzer, the pioneer of hydrogeology in the United States; they signed three papers together, and he supervised part of her work for her first 1927 paper, according to Meinzer himself (Meinzer and Fisher, 1934). Margaret Foster did the water analysis of the Pomperaug basin study (1927). In 1937 she co-signed with her husband and another scientist, Gerald Waring, a book on the thermal springs in the USA (Stearns et al., 1937).

Her publications have been cited hundreds of times, often in the 1940s, 1950s and 1960s but also later, including several times from 2000 to 2016 (from WorldCat and Google Scholar).

The last paper she is known for certain to be the author of is from 1938, the same year she divorced. The last trace of her I could find was in the 1940 US census, where she is mentioned as living in Seattle with both her children.

In addition to these publications, she is also sometimes mentioned as the co-author of two other works (WorldCat has several references to them, where she is sometimes mentioned and sometimes not): "Geology of reservoir and dam sites - geology of the Owyhee irrigation project" and "The Thiem method for determining permeability of water-bearing materials and its application to the determination of specific yield: results of investigations in the Platte River Valley, Nebraska".

\section{Attested bibliography}

- Dowell, Norah E.: Some Phases of the Economic Geography of Rhode Island: A Study of Response to Geographic Environment, PhD thesis, Brown University, Unites States of America, 1916.

- Meinzer, Oscar E. and Stearns, Norah Dowell: A study of groundwater in the Pomperaug Basin, Connecticut, US Geological Survey Water-Supply Paper, 2309, 73-146, available at: http://pubs.usgs.gov, 1927-1929. cited 73 times

- Stearns, Norah Dowell: Laboratory tests on physical properties of water-bearing materials, US Geol. Survey, Water Supply Paper, 596, available at: http://pubs.usgs. gov, 1927. cited 72 times

- Collins, W. D., Fiedler, Albert, Hall, George, Howard, C., McCombs, John, Meinzer, Oscar E., Riffenburg H., and Stearns, Norah Dowell: Contributions to the hydrology of the US, USGS, 1927.

- Stearns, Norah Dowell: Report on the geology and ground water hydrology of the experimental area of the United States Public Health Service at Fort Caswell, NC., Washington: Government Printing Office, Hygienic laboratory bulletin, 147, US Treasury Department house document, 597, 1927. 
- Stiles, Charles Wardell, Crohurst, H. R., Thomson, Gordon E., and Stearns Norah Dowell: Experimental bacterial and chemical pollution of wells via ground water, and the factors involved, Bulletin, Hygienic Laboratory, U.S., 147, 1927.

- Bryan, Kirk, Grover, Nathan Clifford, McGlastein, Harry D., Meinzer, Oscar E., Stearns, Harold T., and Stearns, Norah Dowell: Contributions to the hydrology of the US, USGS, 1928.

- Stearns, Norah Dowell: Annotated Bibliography and Index of Geology and Water Supply of the Island of Oahu, Hawaii, U.S. Geological Survey, Bulletin 3, 78 pp., available at: http://pubs.er.usgs.gov, http://evols.library. manoa.hawaii.edu, 1935.

- Stearns, Norah Dowell: An island is born; Oahu roars up from the deep to claim its place in the Hawaiian group of Polynesia; a story of geological genesis, Honolulu, Hawaii : Honolulu Star-Bulletin Company, Ltd, 1935.

- Stearns Norah Dowell: Significance of limestone in Guam, Guam Recorder, 14, 3, 28-43, 1937. cited 1 time

- Stearns Norah Dowell: Explosive volcanic rocks of Guam, Guam Recorder, 14, 4, 36-37, 1937. cited 1 time

- Stearns, Norah Dowell, Stearns, Harold T., and Waring, G. A.: Thermal springs in the United States Geological Survey, available at: http://books.google.com, Water-Supply Paper 679-B, 206 pp., 1937. 4 editions published in 1937, held by 157 WorldCat member libraries worldwide

- Stearns, Norah Dowell, Pillow lavas of Guam, Guam Recorder, 14, 7-8, 1938. cited 2 times

\section{Scientists and activists}

These women are a source of inspiration not only for their scientific work and their perseverance but also for the other actions they conducted for social justice. In every science quite a few female scientists have linked their own struggle for a place in science to more general social struggles (Chazal, 2006). For example the Russian mathematician Sofia Kovalevskaïa participated in the 1871 Paris Commune, and Irène Joliot Curie was part of the 1936 French Popular Front government, which she left, partly to protest its nonintervention in Spain.

We can identify a first group that worked hard to allow access to education for all by being advocates, like Ethel Skeat Woods or Mary Fairfax Somerville, for the education of girls and young women and often by concretely founding institutions dedicated to it. Elizabeth Thomas Carne built several schools for poor children in the first half of the 19th century in the UK. Elizabeth Cary Agassiz founded a school for girls in Boston (opened from 1856 to 1863) and co-founded the Harvard annex for women in 1879, which would become Radcliffe College. She was its president and then honorary president until 1903. She and her husband organised the 1873-1874 summer schools on Penikese Island (Massachusetts), which they opened to many women in different disciplines. It had lasting influence (Rossiter, 1982). With her father, Mary Emilie Holmes founded a seminary for young Black women in Mississippi in 1892, which later became Mary Holmes College (open until 2005), in memory of her mother (a first attempt to open a school for AfricanAmericans failed due to death threats against the staff). Margaret Gardiner established and directed Aldeburgh School (UK, 1896-1907) with the goal of educating girls in the same way boys were.

The second group is composed of the advocates for women in geology. Some took a stance and spoke out, like Winifred Goldring, unhappy with the treatment of female geologists by many male geologists and palaeontologists, or Margaret Fuller Boos, supporting women studying geology at her university. A fund for female students at Northwestern University now bears her name. Others were members of associations, such as Mary Vaux Walcott, president of the Society of Woman Geographers in 1933; Elizabeth Fisher, who was a representative of MIT Women's Association and one of the officers of the Boston branch of the American Association of American University Women; Gertrude Elles, member of the British Federation of University Women; Madeleine Fritz, with the Canadian Confederation of University Women and the International Federation of University Women; and Kathleen McInerny Sherrard, Honorary Secretary of the Victorian Women Graduates Association (1920-1928) and then of the Australian Federation of University Women (19281938). And some directly initiated concrete changes. Charlotte Hugonin Murchison led the action to open lectures at King's College to women; in 1832, 300 women and men including her and Mary Somerville turned their back to Charles Lyell at his lecture in protest of him denying women the right to attend it. Charlotte knew Charles Lyell, which helped in making him capitulate to women's presence at lectures. In 1903, Annie Barnard Greenly was the instigator of the first female participation in the Geological Section of the British Association for the Advancement of Science conference dinner. Catherine Raisin sometimes paid the fees of her demonstrators herself. Sofia Rudbeck Arrhenius and Naima Sahlbom co-signed, along with 115 other Swedish female scientists, a letter to the king to protest the discrimination of women in science, mentioning two particular cases where women were denied teaching jobs despite having the right credentials. Rachel Workman McRobert campaigned until women had access to the Geological Society of London, which was achieved in 1919.

The third group can be defined as the ones who were committed to gender equality in society - to the right to vote, for example, with Mary Fairfax Somerville, signing the peti- 
tion of John Stuart Mill; Margaret Chorley Crosfield (some of her field notes were even written on the back of suffragettes' pamphlets); or Kathleen McInerny Sherrard, who wrote a paper on the history of Australian women's access to voting and elected positions (Sherrard, 1943). Many had interest in all aspects of women's welfare and advancement, like Fanny Bullock Workman or Cecilia Foley. The expression of those concerns could be quite private, like Mary Anning writing in her notebook what can be considered a protofeminist pamphlet, Woman!. The same concerns could also lead them to participate in women's groups and associations as well as lead to impressive achievements.

For the women's groups and associations we can cite Eunice Newton Foote on the editorial committee for the 1848 Seneca Falls Convention (early meeting of the - white women's rights movement); Catherine Raisin, who founded a discussion club for women (Somerville Club) in the late 1870 s and after her retirement from teaching in 1920 conducted extensive work in women's groups; Margaret Gardiner, who started the Women's Institute in Sussex after she retired; Naima Sahlbom and Margarethe Selenka, who were involved in the women's movement; and Kathleen McInerny Sherrard, who was active in a number of women's organisations, like the Status of Women Council in 1949 and the United Associations of Women.

Special attention should be given to the cases of Maria Ogilvie Gordon and Marie Stopes Roe. Maria Ogilvie Gordon was very dynamic in several organisations: the National Council for Women of Great Britain and Ireland, of which she was president from 1916 to 1920 , and the International Council of Women in the League of Nations (which she formed). She was also honorary president of the Associated Women's Friendly Society and the National Women's Citizens Association. She played an important role in the negotiations for women's representation in the League of Nations. Marie Stopes Roe abbreviated a brilliant scientific career to dedicate herself to her feminist (but also, it must be said, eugenist) interests: she founded several birth control clinics and was also a pioneer in sex education with her book Married Love. She is now mainly known for that aspect of her life (an international NGO promoting contraception and sexual health bears her name).

A fourth group, much smaller in number but significant considering present environmental issues, was formed by precursors to the defence of the environment. Katherine Fowler-Billings and Annie Barnard Greenly, a member of the RSPCA (Royal Society for the Prevention of Cruelty to Animals), defended non-human species. Luella Owen was an early advocate for the preservation of caves: "The gift of beauty should always be honoured and protected for the public good." And Elizabeth Fisher argued for conservation.

A fifth group includes female scientists involved in diverse social and political causes, like Cecilia Foley or Henderina Klaassen Scott. More specifically, Lydia Francis Child was an abolitionist of slavery, and Mary Emilie Holmes worked along her parents with freedmen. Elizabeth Thomas Carne, rich after her parents death, became a philanthropist, spending a lot of her money on charities, building schools (see above) and tackling poverty issues among miners. At least two went into politics: Maria Ogilvie Gordon, after 1919 and the death of her husband, with the Liberal Party (UK), and Lucy Wills, who during the last decade of her life was a Labour Party councillor (UK). At least four others were involved in the peace movement: Naima Sahlbom, against chemical weapons in particular; Kathleen McInerny Sherrard, with the Women's International League for Peace and Freedom; Margarethe Selenka; and Pelageya Yakobevna Polubarinova-Kochnia.

Finally, it should also be said that quite a few of the women mentioned in this paper took a part in the "war effort" during WWI and WWII on the caring side and sometimes on the offensive one, helping the Allied forces with their scientific skills and in two cases taking part in the Resistance.

During WWI Gertrude Elles was involved with the Red Cross, Julia Gardner served as an auxiliary nurse in France for the same Red Cross from 1917 to 1919, Lucy Wills was also a voluntary nurse, and Isabel Peyronnet-Browne helped trace wounded or missing soldiers. Ida Ogilvie was very active with a Barnard College campaign to recruit young women to do farming during vacations to compensate for labour shortage.

During WWII Lucy Wills was a pathologist at an emergency medical service, and Kathleen Blackburn assisted some German prisoners in carrying out pollen analyses from Featherstone Castle camp through the YMCA. On the offensive side, Julia Gardner was a member of the Military Geology Unit and leader of the group "The Dungeon Gang". She helped prepare maps for the armed forces and found Japanese beaches used to launch incendiary balloon bombs by identifying shell fragments in the sand-filled ballast of the balloons. Elizabeth Soshkina was part of a group study of oil deposits. Dorothy Wyckoff organised training in photogrammetry and mapping and produced field maps for the Military Geology Unit of the USGS, which were used to plan assault operations. More morally questionable is the participation of Margaret Foster in the Manhattan Project. Two were active in resisting the Nazis: mineralogist and petrologist Eugenia Zaniewska-Chlipalska with the Armia Krajowa (Home Army) in Poland and Czech mineralogist Ludmila Kaplanova Slavikova, whose strong political commitment to resisting Nazism knew a tragic fate. She and her husband were arrested in 1943; she died soon after in Auschwitz-Birkenau.

Struggling with sexist discrimination is a trigger to tackle such discrimination not only for oneself but also for the other women and often with them. First of all their actions went towards access to education at every level and for all as well as access to all scientific institutions 


\section{Obliteration}

Patriarchy works in many ways to prevent us from registering and remembering that women can do science, are doing it and have done it: from the instant seizing of authorship of their findings to oblivion later on and from lack of attention to forgetting studies on the role of women in science history. Margaret Rossiter has described this ensemble of phenomena and named it the Matilda effect (Rossiter, 1993).

Few people are aware of how many women scientists were active before the 1950s. I was first surprised to discover that many female geoscientists in the 19th century and the beginning of the 20th century. All the people I have been talking to about it were surprised as well, as were people listening or attending my presentations at conferences or at my workplace - even the ones interested and involved in diversity issues. Cynthia Burek reports (Burek and Higgs, 2007; Burek, 2008) that only $10 \%$ (of 550 respondents) named a geologist when asked to name 10 female scientists in different Western European countries, and it was always Mary Anning. Yet not only have those 210 women existed and done scientific research, but they have also been quite often recognised during their lifetime in one way or another. Thus their absence from our collective memories is even more surprising. What mechanisms have obliterated them?

\subsection{Obliteration was quasi-synchronous to their work}

Some men took credit one way or another for women's work (see Sect. 4 "Discrimination").

\subsection{Recognition during their lifetime but obliteration quickly after}

The fact that quite a few among the early female geoscientists were recognised for their work during their lifetime is not self-evident. Among the 210 identified in this paper, there is proof of recognition for 34 of them. Some received due recognition, like Mary Anning, Caroline Birley, Pauline Crié Oehlert, Hedwig Kniker, Helen Skewes Plummer, Isabel Cookson, Irene Crespin and Ellen Louise Mertz. Some received awards or even many, such as Anna Amalitskiya, Inge Lehmann, Katherine Van Winckle Palmer, Tilly Edinger and Ethel Dobbie Curie. The Lyell Medal of the London Geological Society was awarded to Maria Ogilvie Gordon in 1932, Eleanor Wynne Edwards Reid in 1936, Helen MuirWood in 1958 and Doris Livesey Reynolds in 1960. In total, as of 2019 this medal counts 10 female awardees only. Other geological prizes were awarded to women: the Murchison Medal to Gertrude Elles in 1919 and to Ethel Shakespear Wood in 1920 (in total, as of 2019 this medal counts four female awardees only) and the Morris prize in geology to Edith Goodyear in 1902. General scientific prizes were awarded as well: Dagmara Maximilianovna RauzerChernousova received the Lenin prize (the highest science award in the Soviet Union), and Ellen Louise Mertz received the Technical University's gold medal in 1974. Others received honorary $\mathrm{PhD}$ or DSc degrees: Maria Gortynskaia Pavlova in 1916, Ethel Skeat Woods in 1905 from Trinity College in Dublin, Inge Lehmann in 1964 from Columbia University and in 1968 from the University of Copenhagen, Emma Hüther Richter in 1949 from the University of Tübingen, Winifred Goldring twice, Elizabeth Soshikina in 1946 (in biology), Irene Crespin in 1960, and Tilly Edinger. Some were awarded funding, which was perhaps the most significant form of recognition for the recipients. The Lyell Fund was awarded to Catherine Raisin in 1893, Gertrude Elles in 1900, Helen Muir-Wood in 1930 and Eileen Hendricks in 1958. The Murchison Fund from the Geological Society was awarded to Jane Donal Longstaff in 1898, Elizabeth Anderson Gray in 1903, Ethel Skeat Woods in 1908, Eleanor Wynne Edwards Reid in 1919 and Emily Dix in 1936 (and only six more women by 2019). The Daniel Pidgeon Fund from the British Geological Survey, a fund aimed at young researchers, was awarded to Helen Drew in 1906 and Ida Slater Lees in 1907 to undertake field work. The Wollaston fund of the Geological Society of London was awarded to Ethel Wood Shakespear in 1904. The Henry Stopes Memorial Fund was awarded to Mabel Tomlinson 1961. In 1906 Marie Stopes Roe received funds from the Royal Society to do research in Japan, and Marie Bentivoglio was awarded the 1851 Research Fellowship of the Royal Commission in 1922. Recognition during their lifetime does not, however, mean for women that they were remembered later. Their discoveries are not forgotten, but the fact that they are the results of women's work is. Two emblematic examples of this are the Lehmann discontinuity and the Elles and Wood (1910-1918) reference work on graptolites. The first one is known by basically any geologist, and the second has been a reference for palaeontologists and stratigraphers until at least 2009. But the fact that the Lehmann discontinuity was discovered by a woman, Inge Lehmann, was not perceived by many geologists until recently, and the Elles and Wood (Shakespear) monograph has been largely cited by scientists more often than not ignoring that they were women $(\mathrm{Bu}-$ rek, 2014). A general sexist preconception that scientists are men, coupled with the practice of citing papers only by surnames and the many bibliographies giving full references with only initials of first names, does not help to identify that it is not the case, neither nowadays nor in the past. Lasting tributes (often posthumous) to at least 13 of them do not seem to have succeeded in making their personalities widely known, at least in the geoscience community. This is probably because they are very discreet, such as fossil or present species names (e.g. after Caroline Birley, Maria Ogilvie Gordon, Igerna Sollas, Julia Gardner); remote places (Margaret Fuller Boos: a mountain peak; Maria Klenova: a valley north of Greenland, a seamount and a crater on Venus); known only locally (Institute of Geodynamics in Bucharest, named after Sabba Stefanescu; scholarship in the name of Elizabeth 
Fisher at Wellesley College for women graduates) or by a small number of specialists of specific subjects, such as the Madeleine Fritz Annual Lecture in Palaeontology (annual event with female speakers at the Royal Ontario Museum) and Madeleine Fritz Travel Grants for the Advancement of Studies in Palaeontology or the Annie Greenly Fund for detailed geological mapping established by the Geological Society of London; or too recent to evaluate their impact (exhibitions of Orra White Hitchcock's work in 2011 at the Mead Art Museum at Amherst College and in 2018 at the American Folk Art Museum). It would be interesting to know how much the American Geophysical Union (AGU) medal named after Inge Lehmann from 1997 played a role in her growing recognition as well as how much the Alice Wilson Awards for emerging women scholars by the Royal Society of Canada, established in 1991, played a role in the (much more modest) acknowledgement of Alice Wilson.

\subsection{Research on women scientists is not sufficiently well known and suffers from obliteration itself}

To find these 210 women geoscientists I did original research in one case and reviewed the literature for the other 209. Thus literature on these women does exist (see at least all the references listed below), but somehow it goes unnoticed by most people, even in the (geo)scientific community. Even the most remembered, Mary Anning, was forgotten until the end of the 20th century; she was remembered by the scientific community from at least 1999 , with a symposium dedicated to her, and by a larger audience from the 1990s (with several children's books about her from 1991). One of the main sources I used, the special publication of the Geological Society coordinated by Burek and Higgs, was published in 2007. I was finishing my $\mathrm{PhD}$ and then left the academic world for 8 years, having to deal with sexist issues myself (see Vincent, 2017). So it is not too surprising that I missed out on this publication. But what about the works of Margaret Rossiter (Rossiter, 1982) on all sciences, including geosciences, or Mary Creese on geosciences (Creese and Creese, 1998, 2010, 2015), whose first papers on the subject were published in 1974 (Rossiter, 1974) and 1994 (Creese and Creese 1994), respectively? And regarding the great dictionary coordinated by Ogilvie and Harvey published in 2000 (Ogilvie and Harvey, 2000), how is it possible that none of my professors ever mentioned it (to be fair, they hardly mentioned the history of science at all), and why did I never come across it on the library shelves? Well, maybe because they are not available in many libraries in France. Table 4 shows that major books on the history of women in science are present at only a few libraries at French universities, knowing that there are nearly 500 academic libraries at 67 universities (in 50 different cities and areas) in France. As a comparison, textbooks that are easy to find are present at several dozen libraries, often at more than a hundred of them. But when a book is at fewer than 10 academic libraries in France, students clearly have no chance to discover it by just browsing the shelves. That is definitely not an appropriate distribution for a book which is a reference like Ogilvie and Harvey (2000).

Although a few titles on women in the history of science (Poirier, 2002; Chazal, 2006; Détrez, 2016) are available at 40 to 60 university libraries, those are all popularisation books in French, which makes them more accessible to students if they opened them but harder to come upon as they are so thin (three under 200 pages and two between 300 and 400 , with an actual thickness from 0.7 to $2.7 \mathrm{~cm}$ ); they do not appear on the shelves. This is not the case for the three (groups of) publications mentioned in Table 4, which, when on a shelf, make quite an impression (1500 pages and $9 \mathrm{~cm}$ for The Biographical Dictionary of Women in Science). Even if you do not open it, you cannot imagine any longer that female scientists were rare in the past. It is a detail, but it does not mean it has no impact, especially when there are many such details at work keeping the history of women scientists in discreet corners. A few possible leads to tackle these successive obliterations might be to

- pursue historical research and lobby for it to be funded;

- continue presentations and sessions at conferences and the publication of papers and books;

- improve the distribution of the research that already exists (e.g. by at least asking your local academic library for the Ogilvie and Harley dictionary);

- create the missing Wikipedia pages on each of the pioneer female geoscientists using the existing literature;

- cross-reference these in pages listing women in science and the history of science in general (which tend to list mostly or even only men) as well as prize lists;

- enrich and promote existing popularisation blogs like TrowelBlazers, Letters from Gondwana or Women in American Paleontology;

- include some of these female figures in our teaching so our students discover them sooner than we did;

- add some in our textbooks (we did it with two colleagues in a recent French geology textbook; Krémeur et al., 2019);

- create and distribute reading lists about women in science, e.g. on social media dedicated to books;

- offer our daughters and nieces as well as sons and nephews books such as Women in Science: 50 fearless Pioneers who changed the world (Ignotofsky, 2016) and pressure publishers to translate them in other languages than English or design new ones! 
Table 4. Availability of some key titles on women in science at French university libraries.

\begin{tabular}{lrr}
\hline & \multicolumn{2}{c}{ Data extracted from SUDOC } \\
\cline { 2 - 3 } References & Number of university libraries & Number of cities \\
\hline Ogilvie and Harvey (2000) & 7 & 2 \\
Creese and Creese $(1998,2010,2015)$ & 3 & 1 \\
Rossiter (1982) & 3 & 1 \\
\hline
\end{tabular}

\section{Conclusions}

A list of 210 female geologists and palaeontologists (all earth sciences included but no archaeologists, prehistorians, astronomers or planetary scientists) active in research between 1800 and 1929 has been established. This list is certainly not exhaustive. Data have been found in the literature for 209 of them, and new data are presented on hydrogeologist Norah Dowell Stearns, possibly the first full-time female hydrogeologist. Discrimination has marked all these women scientists' studies and careers: from impossible or difficult access to university as students and academic or private research positions to the attribution of their own work to men they worked with or for in addition to social disapprobation and careers slowed down or cut short to take care of children or a husband, without forgetting that, for some, sexism was not the only prejudice they had to fight against. Many women never dared to start or had to leave university early, but against all odds, some managed it and did research at some point in their lives or even their whole lives. To overcome difficulties, in addition to coming from relatively to very comfortable economic backgrounds (the large majority of the ones for which this information is available), a third relied on supportive parents (in a broad sense), more than half relied on the absence of a husband or married later in life, and at least a third developed strong sorority networks. They received support from some male geologists, mostly husbands and mentors, more often than not appropriating the women's work or having at least sexist motivations. Many of these 210 women earth scientists have done or contributed to major scientific work. To understand how absent they are from our collective memory, patriarchal obliteration mechanisms, named "the Matilda effect" by Margaret Rossiter, have thus to be considered: direct appropriation of their results by men, oblivion later on of women professionally recognised while they were alive and, as an additional layer, the way science history is written and transmitted, the studies on the role of women in science still being marginalised. Ways we could fight this oblivion to which their personalities are subject to are to continue digging into pre-1930 earth science publications, especially in subjects on which apparently only men worked, and to keep spreading knowledge about them in the scientific community and to the general public. Curiosity and knowledge are far from being the only interest; the obstacles these pioneer female earth scientists met while pursuing their studies and research enlighten the persisting unequal gender balance in earth sciences and the struggles of female geoscientists today, as also suggested by Burek and Higgs in the introduction of their 2007 paper collection. Learning from the fate of pioneer female geologists should help us understand our own situation and provide some clues to tackle it by taking inspiration from these amazing role models, who often faced adversity collectively and beyond their own individual fate. Because even if some of the obstacles they met have been overcome, e.g. universities are no longer forbidden to us women, some are still very common, such as the lack of women in professor or researcher positions, reflecting a sexist selection still at work and discouraging women from applying to such jobs. And some obstacles have only come to light in recent years, such as masculine violence towards women, including sexual harassment in the workplace.

Data availability. The original research on Norah Dowell Stearns is presented in its entirety in Sect. 8, and the rest of the paper is a bibliographical work: the data used can be found in the papers cited in the reference list.

Supplement. The supplement related to this article is available online at: https://doi.org/10.5194/adgeo-53-129-2020-supplement.

Competing interests. The author declares that there is no conflict of interest.

Special issue statement. This article is part of the special issue "Diversity and equality in the geosciences (EGU2019 EOS6.1 \& US4, AGU2018 ED41B, JpGU2019 U-02)". It is a result of the EGU General Assembly 2019, Vienna, Austria, 7-12 April 2019.

Acknowledgements. Thanks to Claudia Jesus Rydin for encouragement in pursuing this topic, to Michael Pettersson for translating information from Swedish on Naima Sahlbom and Sofia Rudbeck, to Lisa Wingate and an anonymous colleague at the 2019 EGU meeting in Vienna for highlighting to me Eunice Newton Foote, to Sophie Violette for helpful feedback on the first draft, to the reviewers for their suggestions (one anonymous reviewer, Anny Cazenave, Lisa White and Luis Farina Busto), and to Sophie Pietrucci and 
Michael Pettersson for English proofreading (all remaining mistakes are mine).

For a different approach to the lives of pioneer female geologists and naturalists, the novels Remarkable Creatures (about Mary Anning and Elizabeth Philpot) by Tracy Chevalier and Unsheltered (about botanist Mary Treat) by Barbara Kingsolver are wonderful readings.

Review statement. This paper was edited by Claudia Jesus-Rydin and reviewed by Anny Cazenave, Lisa D. White, Luis Farina Busto and one anonymous referee.

\section{References}

American Museum of Natural History - Inge Lehmann: Discoverer of the Earth's Inner Core, available at: https://www.amnh. org/learn-teach/curriculum-collections/earth-inside-and-out/ inge-lehmann-discoverer-of-the-earth-s-inner-core, last access: 2019.

Anonymous: Caroline Birley, Geol. Mag., 4, 143-144, 1907.

Anonymous: 16th meeting of the GEBCO Sub-Committee on Undersea Feature Names, International Hydrographic Bureau, Monaco, 2003.

Anonymous: Pelageya Yakovlevna Polubarinova-Kochina (in commemoration of the 110th anniversary), Water Resour., 36, 610 611, https://doi.org/10.1134/S0097807809050145, 2009.

Aldrich, M.: Women in Paleontology in the United States 1840-1960, Earth Sci. Hist., 1.1, 14-22, https://doi.org/10.17704/eshi.1.1.18226u21t535x768, 1982.

Ashcraft, D.: Women's work: a survey of scholarship by and about women, Haworth Press, New York, USA, ISBN 978-078900233-4, 1998.

Bennett, J. and Mather, J.: Eileen Mary Lind Hendriks (1887-1978), A Centenary Celebration of the First Female Fellows of the Geological Society of London, The Geological Society, London, UK, 21 May 2019.

Björnsson, H.: The Glaciers of Iceland, a Historical, Cultural and Scientific Overview, 1st Edn., Atlantis Advances in Quaternary Science, 2, edited by: O'Cofaigh, C., Atlantis Press, ISBN 9789462392069, 2017.

BnF Data - Elisabeth Jerémine (1879-1964), available at: https:// data.bnf.fr/fr/11113820/elisabeth_jeremine/, last access: 2019.

Bowie, R.: Freedom and Equality - Women in Geology, British Geological Survey, 2007.

Branagan, D. F. (Ed.): Rocks, Fossils, Profs. Geological Sciences in the University of Sydney 1866-1973, Science Press, Sydney, 184 pp., 1974.

Briscoe Center for American History - the University of Texas at Austin - A Guide to the Hedwig Thusnelda Kniker Family Papers, 1887-1987, available at: https://legacy.lib.utexas.edu/taro/ utcah/03342/cah-03342.html, last access: 2019.

Brook man stamps - A little history on the 22ND (1955-56) duck stamp artist, available at : http://www.brookmanstamps. com/Netcat/federal/rw22info.htm, last access 2019.

Bryan, M. L., Bair, B., de Angury, M., and Addams, J.: The Selected Papers of Jane Addams: Vol. 1: Preparing to Lead, 1860-81, University of Illinois Press, Champaign, USA, 209-212, 2002-2010.
Burek, C. V.: The Role Women have Played in Developing the Science of Geology 1797 to 1918-19 in Britain, in: Open University Geological Society Journal, 29, 2, symposium edition 2008.

Burek, C. V.: The First Female Fellows and the Status of Women in the Geological Society of London, Geol. Soc. Spec. Publ., 317.1, 373-407, https://doi.org/10.1144/SP317.21, 2009.

Burek, C. V.: The Contribution of Women to Welsh Geological Research and Education up to 1920, P. Geol. Assoc., 125.4, 480 492, https://doi.org/10.1016/j.pgeola.2014.07.007, 2014.

Burek, C. V.: Two Forgotten Female Fellows of the Geological Society: Mabel Tomlinson and Isobel Knaggs, A Centenary Celebration of the First Female Fellows of the Geological Society of London, The Geological Society, London, UK, 21 May 2019.

Burek, C. V. and Cleal, C. J.: The Life and Work of Emily Dix (1904-1972), Geol. Soc. Spec. Publ., 241.1, 181-96 https://doi.org/10.1144/GSL.SP.2003.207.01.14, 2005.

Burek, C. V. and Higgs, B.: The Role of Women in the History and Development of Geology: An Introduction, Geol. Soc. Spec. Publ., 281.1, 1-8 https://doi.org/10.1144/SP281.1, 2007.

Burek, C. V. and Kölbl-Ebert, M.: The Historical Problems of Travel for Women Undertaking Geological Fieldwork, Geol. Soc. Spec. Publ., 281.1, 115-122, https://doi.org/10.1144/SP281.7, 2007.

Burek, C. V. and Malpas, J. A.: Rediscovering and Conserving the Lower Palaeozoic "Treasures" of Ethel Woods (Neé Skeat) and Margaret Crosfield in Northeast Wales, Geol. Soc. Spec. Publ., 281.1, 203-226, https://doi.org/10.1144/SP281.12, 2007.

Burke, J.: Madeleine Alberta Fritz, l'Encyclopédie Canadienne. Historica Canada, available at: https://thecanadianencyclopedia. ca/fr/article/madeleine-alberta-fritz (last access: 2019), 20082014.

Bygott, U. and Cable, K. J.: Pioneer Women Graduates of the University of Sydney 1881-1921, The University of Sydney, Sydney, NSW, Australia, 27-29, 1985.

Chaloner, B.: Marie Stopes - Palaeobotanist, in: Open University Geological Society Journal, 29, 2, symposium edition 2008.

Chazal, G.: Les Femmes et La Science, Ellipses, Paris, France, 2006.

Clary, R. M. and Wandersee, J. H.: Great Expectations: Florence Bascom (1842-1945) and the Education of Early US Women Geologists, Geol. Soc. Spec. Publ., 281.1, 123-135, https://doi.org/10.1144/SP281.8, 2007.

Collective letter: Till Konungen, Hasse W. Tulibergs boktr. Stockholm, available at: http://www2.ub.gu.se/kvinndata/portaler/ kunskap/kaf/konungen1906.pdf (last access: 2019), 1906.

Creese, M. R. S.: Fossil Hunters, a Cave Explorer and a Rock Analyst: Notes on Some Early Women Contributors to Geology, Geol. Soc. Spec. Publ., 281.1, 39-49 https://doi.org/10.1144/SP281.3, 2007.

Creese, M. R. S.: African, Australian, New Zealand, and Canadian Women in Science: Nineteenth and Early Twentieth Centuries: A Survey of Their Contributions, Scarecrow Press, Lanham, USA, 2010.

Creese, M. R. S. and Creese, T. M.: British Women Who Contributed to Research in the Geological Sciences in the Nineteenth Century, The British Journal for the History of Science, 27.1, 23 54, https://doi.org/10.1017/S0007087400031654, 1994.

Creese, M. R. S. and Creese, T. M.: Ladies in the laboratory? American and British Women in Science, 1800-1900: a Survey of 
their Contributions to Research, Scarecrow Press, Lanham, USA, 1998.

Creese, M. R. S. and Creese, T. M.: Ladies in the Laboratory II-West European Women in Science, 1800- 1900: A Survey of Their Contributions to Research, Scarecrow Press, Lanham, USA, 2004-2010.

Creese, M. R. S. and Creese, T. M.: Ladies in the Laboratory IV: Imperial Russia's Women in Science, 1800-1900: A Survey of Their Contributions to Research, Rowman and Littlefield, Lanham, USA, 2015.

Daniel Victor Oehlert (1849-1920), available at: http://emig.free.fr/ GENEALOGIE/Fig-Emig/Oehlert.html, last access: 2019.

Daring to dig - Florence Bascom (1862-1945), available at: http: //www.daringtodig.com/bascom/, last access: 2019.

Daring to dig - Julia Gardner (1882-1960), available at: http: //www.daringtodig.com/gardner, last access: 2019.

Daring to dig - Orra White Hitchcock (1796-1863), available at: http://www.daringtodig.com/hitchcock, last access: 2019.

Davis, L. E.: Mary Anning of Lyme Regis: 19th century Pioneer in British Palaeontology, Headwaters, 26, 96-126, 2009.

Davis, S. N. and Davis A. G.: Hydrogeology in the United States 1780-1950, Department of Hydrology and Water Resources, University of Arizona, Tucson, p. 140, 2005.

Détrez, C.: Les Femmes peuvent-elles être de grands hommes - Sur l'effacement des Femmes de l'Histoire, des arts et des sciences, Égale à Égal, Belin, Paris, 2016.

Dietrich, R. V.: Memorial to Anna I. Jonas Stose 1881-1974, GSA, 1977.

Dominus, S.: Women Scientists Were Written Out of History - its Margaret Rossiter's Lifelong Mission to Fix That, Smithsonian Magazine, October 2019.

Dowell, N. E.: Some Phases of the Economic Geography of Rhode Island: A Study of Response to Geographic Environment, $\mathrm{PhD}$ thesis, Brown University, USA, 1916.

Dyball, R. and Carlsson, L.: Ellen Swallow Richards: Mother of Human Ecology?, Human Ecology Review, Special Issue: Human Ecology - A Gathering of Perspectives: Portraits from the Past - Prospects for the Future, 23.2, 2017.

Elles, G. L. and Wood, E. M. R : A Monograph of British Graptolites, Palaeontogr. Soc. (Monogr.), 1910-1918.

Encyclopaedia Britannica - Inge Lehmann - Danish seismologist, available at: https://www.britannica.com/biography/ Inge-Lehmann, last access: 2019.

Encyclopedia of Australian Science - Quodling, Florrie Mabel (1901-1985), available at: http://www.eoas.info/biogs/ P001786b.htm, last access: 2019.

Eyczewska, J.: Eugenia Zaniewska-Chipalska 1899-1980, Ann. Soc. Geol. Pol., 617-622, 1981.

Falcon-Lang, H.: Marie Stopes, The Discovery of Pteridosperms And The Origin of Carboniferous Coal Balls, edited by: Oldroyd, D., Earth Sci. Hist., 27.1, 78-99, https://doi.org/10.17704/eshi.27.1.7061723043w72561, 2008.

Fraser, H. E. and Cleal, C. J.: The Contribution of British Women to Carboniferous Palaeobotany during the First Half of the 20th Century, Geol. Soc. Spec. Publ., 281.1, 51-82, https://doi.org/10.1144/SP281.4, 2007.

Frost, C.: Recipe for Success: Field Geologist Katharine FowlerBillings (1902-1997), Geophys. Res. Abstr., 4067, 19th EGU General Assembly, Vienna, Austria, 23-28 April 2017.
Goodhue, T.: Mary Anning: the Fossilist as Exegete, Endeavour, 2005.

Gould, P.: Femininity and the physical sciences 1880-1914, Cambridge, unpublished $\mathrm{PhD}$ thesis, 1998.

Government of Canada - 66 Ottawa Geology, available at: http:// www.science.gc.ca/eic/site/063.nsf/eng/97252.html, last access: 2019.

Grahame, R.: Sherrard, Kathleen Margaret Maria (1898-1975), Australian Dictionary of Biography, National Centre of Biography, Australian National University, available at: http://adb.anu. edu.au/biography/sherrard-kathleenmargaret-maria-11681 (last access: 2019), 2002.

Gries, R.: Anomalies: Pioneering Women in Petroleum Geology: 1917-2017, JeWel Publishing LLC, Denver, CO, 2017.

Hart, J. K.: The Role of Women in British Quaternary Science, Geol. Soc. Spec. Publ., 281.1, 83-95 https://doi.org/10.1144/SP281.5, 2007.

Higgs, B. and Jackson, P. N. W.: The Role of Women in the History of Geological Studies in Ireland, Geol. Soc. Spec. Publ., 281.1, 137-53, https://doi.org/10.1144/SP281.9, 2007.

History of American Women - Elizabeth Cary Agassiz, available at: http://www.womenhistoryblog.com/2014/02/ elizabeth-cary-agassiz.html, last access: 2019.

Holmes, M. A., O'Connell, S., Frey, C., and Ongley, L. K.: Academic specialties in U.S. are shifting; Hiring of Women Geoscientists is Stagnating, Eos, https://doi.org/10.1029/2003EO430002, 2011.

Howes, R. and Herzenberg, C. L.: Their Day in the Sun: Women of the Manhattan Project, Temple University Press, 1999.

Hulbe, C. L., Wang, W., and Ommanney, S.: Women in Glaciology, a Historical Perspective, J. Glaciol., 56, 944-964, 2010.

Ignotofsky, R.: Women in Science: 50 Fearless Pioneers Who Changed the World, First edition, Ten Speed Press, New York, 2016.

Jackson, P. N. W.: Grenville Arthur James Cole (1859-1924): The Cycling Geologist, Geol. Soc. Spec. Publ., 287.1, 135-147, https://doi.org/10.1144/SP287.11, 2007.

Jackson, P. N. W.: William Thompson (1805-1852): Zoologist and Biogeographer, The Irish Naturalists Journal, 287.1, 119-122, 2009.

Jackson, P. N. W. and Spencer Jones, M. E.: The Quiet Workforce: The Various Roles of Women in Geological and Natural History Museums during the Early to Mid-1900s, Geol. Soc. Spec. Publ., 281.1, 97-113, https://doi.org/10.1144/SP281.6, 2007.

Jackson School Museum of Earth History - Hedwig T. Kniker (1891-1985), available at: http://www.jsg.utexas.edu/ $\mathrm{npl} /$ history/geologists/hedwig-t-kniker-1891-1985, last access: 2019.

Jones, J. L. and Scharnberger, C. K.: Remembering Anna I. Jonas Stose: Establishing the Foundation of Appalachian Geology, 47th Annual Meeting of the Geol Soc Am Northeastern Section, Hartford, USA, 2012.

Kölbl-Ebert, M.: Charlotte Murchison (Née Hugonin) 1788-1869, Earth Sci. Hist., 16, 39-43, https://doi.org/10.17704/eshi.16.1.97014235w8u4k414, 1997.

Kölbl-Ebert, M.: The role of British and German women in early 19th-century geology: a comparative assessment, Geol. Soc. Spec. Publ., 281.1, 155-163, https://doi.org/10.1144/SP281.10, 2007. 
Kölbl-Ebert, M. and Turner, S.: Towards a History of Women in the Geosciences, Geol. Soc. Spec. Publ., 442.1, 205-16, https://doi.org/10.1144/SP442.16, 2016.

Krémeur, A.-S., Vincent, A., and Coltice, N.: Géologie, Géol, Fluoresciences, Dunod, Malakoff, France, ISBN 9782100801091, 2019

Laming, S. and Laming, D.: Etheldred Benett (1776-1845): The First Woman Geologist?, Geol. Soc. Spec. Publ., 281.1, 247-249 https://doi.org/10.1144/SP281.14, 2007.

Larsen, K.: The Women Who Popularized Geology in the 19th Century, Springer Science+Business Media, New York, USA, 2017.

Letters from Gondwana - Forgotten women of paleontology: Irene Crespin, available at: https://paleonerdish.wordpress.com/2018/ 10/05/forgotten-women-of-paleontology-irene-crespin/, last access: 2019.

Letters from Gondwana - Forgotten women of paleontology: The Newnham quartet, available at: https://paleonerdish.wordpress.com/2016/10/19/

forgotten-women-of-paleontology-the-newnham-quartet/, last access: 2019.

Lewis, C.: Two for the price of one: Doris Reynolds (1899-1985), A Centenary Celebration of the First Female Fellows of the Geological Society of London, The Geological Society, London, UK, 21 May, 2019.

Lobacheva, S. V.: On the History of Russian Paleontology, Paleontol. J., 41.2, 222-26, https://doi.org/10.1134/S003103010702013X, 2007.

Meinzer, O. E. and Fisher, V. C.: Tests of permeability with low hydraulic gradients, Reports and papers, Hydrology, 1934.

Meinzer, O. E. and Stearns, N. D.: A study of groundwater in the Pomperaug Basin, Connecticut, USGS Water-Supply Paper, 2309, 73-146, available at: http://pubs.usgs.gov, 1927-1929.

Melfi, T.: Hidden Figures (film), 2016.

Monteigh, J.: Memorial to Madeleine Alberta Fritz 1896-1990, Geol. Soc. Am., 95-98, 1992.

Nalivkin, V.: Nashi Pervye Zhenshchinye-geologi (Our First Women Geologists), Nauka, Leningrad, USSR, 1979.

Ogilvie, M. B. and Harvey, J. D. (Eds.): The Biographical Dictionary of Women in Science: Pioneering Lives from Ancient Times to the Mid-20th Century, Routledge, New York, USA, 2000.

Orr, M.: Collecting Women in Geology: Opening the International Case of a Scottish Cabinétière, Eliza Gordon Cumming (18151842), A Centenary Celebration of the First Female Fellows of the Geological Society of London, The Geological Society, London, UK, 21 May 2019.

Osborne, R.: Des fantômes tapis dans la roche: l'irrésistible épopée de la géologie, Éditions de l'Évolution, Paris, France, 2013.

Pennington, C.: The Historic Role of Women Scientists at BGS and a Look at What is Happening Today, GeoBlogy, British Geological Survey, 2015.

Philadelphia Area Archives Research Portal - Dorothy Burr Thompson diaries and papers, available at: https://tripod.brynmawr.edu/permalink/01TRI_INST/1fa7h1r/ alma991009615049704921, last access: 2019.

Poirier, J.-P.: Histoire des femmes de science en France: du Moyen Age à la Révolution, Pygmalion/Gérard Watelet, Paris, France, 2002.

Proffitt, P. (Ed.): Notable Women Scientists, Gale Group, Farmington Hills, Michigan, USA, 1999.
Reed, C. and Cannon, W. J.: Marine Science: Decade by Decade, Infobase Publishing, USA, ISBN 9780816055340, 2009.

Rossiter, M. W.: Women Scientists in America before 1920: Career patterns of over five hundred women scientists of the period reveal that, while discrimination was widespread, many women were working hard to overcome it, Am. Sci., 62.3, 312-323, 1974.

Rossiter, M. W.: Women Scientists in America: vol. 1 Struggles and Strategies to 1940, The John Hopkins University Press, Baltimore and London, 1982.

Rossiter, M. W.: The Matthew Matilda Effect in Science, Soc. Stud. Sci., 23.2, 325-341, 1993.

Russel Fink Gallery: Stearns, Stanley, available at: https://store. russellfinkgallery.com/stearnsstanley.htmlT, last access 2019.

Sarjeant, W. A. S.: Geologists and the History of Geology: An International Bibliography from the Origins to 1978, Arno Press, New York, 1978-1987.

Schneiderman, J.: Growth and Development of a Woman Scientist and Educator, Earth Sci. Hist., 11.1, 37-39, https://doi.org/10.17704/eshi.11.1.bu10535687q157g0, 1992.

Schneiderman, J.: A Life of Firsts: Florence Bascom, GSA Today, 8-9, 1997.

Schmid, R.: Agnes Arber née Robertson (1879-1960): fragments of her life, including her place in biology and in women's studies, Ann. Bot., 88, 1105-112, https://doi.org/10.1006/anbo.2001.1553, 2001.

Science.ca - Alice Wilson Géochimie et géochronologie, available at: http://www.science.ca/scientists/scientistprofile.php?pID= 274, last access: 2019.

Scientific American - Maria Matilda Ogilvie Gordon: Pioneer Geologist of the Dolomites, available at: https://blogs.scientificamerican.com/history-of-geology/mariamatilda-ogilvie-gordon-pioneer-geologist-of-the-dolomites/, last access: 2019.

Sendino, C.: Ida Slater: a Modern Researcher at the Beginning of 20th century, A Centenary Celebration of the First Female Fellows of the Geological Society of London, The Geological Society, London, UK, 21 May 2019.

Sherrard, K.: The Political History of Women in Australia, Aust. Quart., 15.4, 36-51, https://doi.org/10.2307/20631140, 1943.

Shetterly, M. L.: Hidden Figures: The American Dream and the Untold Story of the Black Women Mathematicians Who Helped Win the Space Race, reprint edition, William Morrow, USA, 2016.

Shrock, R. R.: Elizabeth Florette Fisher, Geology at MIT, 18651965: A History of the First Hundred Years of Geology at Massachusetts Institute of Technology, MIT Press, 400-401, ISBN 978-0-262-19211-8, 1982.

Stearns, H. T.: Memoirs of a Geologist: From Poverty Peak to Piggery Gulch, Hawaii Institute of Geophysics, USA, 1983.

Stearns, N. D.: Laboratory tests on physical properties of waterbearing materials, USGS, Water Supply Paper, 596, 1927.

Stearns, N. D.: Annotated Bibliography and Index of Geology andWater Supply of the Island of Oahu, Hawaii, USGS, Bulletin 3, 78 pp., 1935a.

Stearns, N. D.: An island is born; Oahu roars up from the deep to claim its place in the Hawaiian group of Polynesia; a story of geological genesis, Honolulu, Hawaii: Honolulu Star-Bulletin Company, Ltd, 1935 b. 
Stearns, N. D.: Significance of limestone in Guam, Guam Recorder, 14, 28-43, 1937a.

Stearns, N. D.: Explosive volcanic rocks of Guam, Guam Recorder, 14, 36-37, 1937b.

Stearns, N. D.: Pillow lavas of Guam, Guam Recorder, 14, 7-8, 1938.

Stearns, N. D., Stearns, H. T., and Waring, G. A.: Thermal springs in the United States Geological Survey, 1937.

Svenska dagstidningar, on Sofia Rudbeck Arrhenius, Swedish papers from 1893 and 1894 seen, available at: https://tidningar.kb. se/, last access: 2019.

Svenskt Biografiskt Lexikon - Naima Sahlbom, available at: https: //sok.riksarkivet.se/SBL/Presentation.aspx $? \mathrm{id}=6309$, last access: 2019.

The Canadian Encyclopedia - Alice Wilson, available at: https://www.thecanadianencyclopedia.ca/en/article/ alice-evelyn-wilson, last access: 2019.

Thompson, C.: Maria Graham and the Geological Society, A Centenary Celebration of the First Female Fellows of the Geological Society of London, The Geological Society, London, UK, 21 May 2019.

Transceltic - Elizabeth Catherine Thomas Carne - Cornish geologist, philanthropist, conchologist, financier, banker, natural philosopher and mineral collector, available at: http://www.transceltic.com/cornish/elizabeth-catherine-thomascarne-cornish-geologist-philanthropist-conchologist-financier, last access: 2019.

TrowelBlazers - Anne Phillips - The Curious Case of Miss Phillips' Conglomerate, available at: https://trowelblazers.com/ anne-phillips, last access: 2019.

TrowelBlazers - Barbara Hastings - The Jolly Fast Fossil Hunter, available at: https://trowelblazers.com/ barbara-hastings-the-jolly-fast-fossil-hunter, last access: 2019.

TrowelBlazers - Caroline Birley - This Ardent Geologist, available at: https://trowelblazers.com/ caroline-birley-this-ardent-geologist, last access: 2019.

TrowelBlazers - Charlotte Murchison - Drawn to Science!, available at: https://trowelblazers.com/charlotte-murchison, last access: 2019.

TrowelBlazers - Eileen Guppy - The First Woman Geologist in the British Geological Survey, available at: https://trowelblazers.com/eileen-guppy-the-first-womangeologist-in-the-british-geological-survey, last access: 2019.

TrowelBlazers - Elizabeth Anderson Gray - Girvan Her All..., available at: https://trowelblazers.com/elizabeth-anderson-gray, last access: 2019.

TrowelBlazers - Emily Dix - Fossil Flora in Wartime, available at: https://trowelblazers.com/emily-dix, last access: 2019.

TrowelBlazers - Inge Lehmann - The Woman Who Found the Inner Core, available at: https://trowelblazers.com/inge-lehmann, last access: 2019.

TrowelBlazers - Mary Horner Lyell - A Geology Pioneer, available at: https://trowelblazers.com/mary-horner-lyell, last access: 2019.

TrowelBlazers - Jane Donald Longstaff - Gastropods Galore!, available at: https://trowelblazers.com/jane-donald-longstaff, last access: 2019.
TrowelBlazers - Mary "Polly" Winearls Porter - Crystallography and the Corsi Collection, available at: https://trowelblazers.com/ mary-porter, last access: 2019.

TrowelBlazers - Margarethe Lenore Selenka - Paleontologist, Pacifist, Feminist, available at: https://trowelblazers.com/ margarethe-lenore-selenka, last access: 2019.

TrowelBlazers - Marguerite Thomas Williams - First (and female): America's first Black Geology $\mathrm{PhD}$, available at: https://trowelblazers.com/marguerite-thomas-williams, last access: 2019.

TrowelBlazers - Mabel E. Tomlinson - Inspiring a Generation of Geologists, available at: https://trowelblazers.com/ mabel-e-tomlinson, last access: 2019.

TrowelBlazers - Maria Graham - Uplift and uproar, available at: https://trowelblazers.com/maria-graham, last access: 2019.

Tubb, J. and Burek, C.: Gertrude Elles: the Pioneering Graptolite Geologist in a Woolly Hat, A Centenary Celebration of the First Female Fellows of the Geological Society of London, The Geological Society, London, UK, 21 May 2019.

Turner, S.: Invincible but Mostly Invisible: Australian Women's Contribution to Geology and Palaeontology, Geol. Soc. Spec. Publ., 281.1, 165-202 https://doi.org/10.1144/SP281.11, 2007.

Turner, S., Burek, C. V., and Moody, R. T. J.: Forgotten Women in an Extinct Saurian (Mans) World, Geol. Soc. Spec. Publ., 343.1, 111-153, https://doi.org/10.1144/SP343.7, 2010.

University of California Museum of Paleontology, Berkeley: Annie Montague Alexander, Benefactress of UCMP, available at: https: //ucmp.berkeley.edu/history/alexander.html, last access: 2019.

University of Cambridge - Department of Earth Sciences Cambridge women pioneers in Earth Sciences, available at: https://www.esc.cam.ac.uk/about-us/equalityanddiversity/ cambridge-women-pioneers-in-earth-sciences, last access: 2019.

University of Iowa Libraries - PAPERS OF CARROLL LANE FENTON AND MILDRED ADAMS FENTON, available at: http://www.lib.uiowa.edu/scua/msc/tomsc650/msc602/ fenton.htm, last access: 2019.

Vincent, A.: The Role of Male Violence against Women in Female Under-Representation in (Geo)Sciences, Geophys. Res. Abstr., 2669, 19th EGU General Assembly, Vienna, Austria, 23-28 April, 2017.

Wachtler, M. and Burek, C. V.: Maria Matilda Ogilvie Gordon (1864-1939): A Scottish Researcher in the Alps, Geol. Soc. Spec. Publ., 281, 305-317 https://doi.org/10.1144/SP281.20, 2007.

Warren, W.: Black Women Scientists in the United States, p. 267, Indiana University Press, Bloomington, USA, ISBN 0253336031, 2000.

Williams, T. P. T.: The Role of Annie Greenly in the Elucidation of the Geology of Anglesey, Geol. Soc. Spec. Publ., 281.1, 319-24, https://doi.org/10.1144/SP281.21, 2007.

Worth Point - Four 1971 Artist Proofs STANLEY STEARNS, available at: https://www.worthpoint.com/worthopedia/ four-1971-artistproofs-stanley-20697111, last access: 2019.

Zlotnik, V. A. and Emikh, V. N.: Pelageya Yakovlevna Polubarinova-Kochina (1899-1999): A Soviet Era Mathematician, Ground Water, 45, 383-387, 2007. 